\title{
Production risk and adoption of irrigation technology: evidence from small-scale farmers in Chile
}

\author{
César Salazar ${ }^{1} \cdot$ John Rand ${ }^{2}$
}

Received: 27 March 2015/Accepted: 6 July 2016/Published online: 21 July 2016

(C) The Author(s) 2016. This article is published with open access at Springerlink.com

\begin{abstract}
In most developing countries non-irrigation status often dominates adoption of traditional and modern irrigation technology. In this paper, we study the effect of production risk on irrigation technology choice among small-scale farmers in Chile, applying sample selection and discrete choice models. We find that more educated farmers, with credit access, receiving extension services, and living in communes with more adopters are more likely to use modern irrigation techniques. Moreover, production risk is often associated with adoption of traditional irrigation, and this risk often undermines a shift to more modern irrigation systems. Controlling for pre-conditions that determine irrigation choices clearly improves our understanding of small-scale farmer irrigation adoption decisions and we argue that weaker knowledge about and lower automatic diffusion of modern irrigation is a main obstacle for improving small-scale farmer productivity.
\end{abstract}

Keywords Production risk · Irrigation · Technology adoption

JEL Classification D8 $\cdot \mathrm{O} 13 \cdot \mathrm{Q} 15 \cdot \mathrm{Q} 55$

César Salazar

csalazar@ubiobio.cl

John Rand

John.Rand@econ.ku.dk

1 Department of Economics and Finance and 'Análisis Económico Sectorial Aplicado' Research Group, University of Bio-Bio, Avenida collao 1202, Concepción, Chile

2 Department of Economics, University of Copenhagen, Copenhagen, Denmark 


\section{Introduction}

Since the green revolution, agriculture in developing countries has experienced a technological transformation process principally driven by an increasing demand for agricultural products. It has triggered a massive increase in the adoption of new technologies, such as the use of chemical inputs, pesticides, traditional irrigation, and high-yielding seed varieties, with significant benefits in terms of productivity and poverty reduction (Evenson and Gollin 2003). However, concerns have lately been raised on the grounds of sustainability, as the intensive use has consequences for environment and human health (Ruttan 2002).

The adoption of traditional irrigation methods has shown to be beneficial to reduce farmers' vulnerability to weather conditions, making production and incomes more stable. However, traditional irrigation has also increased the pressure on water reservoirs and created pollution problems. ${ }^{1}$

The aim of this paper is to study the effect of production risk on irrigation technology choices and discuss adoption of modern irrigation in settings where most rural households depend exclusively on rainfall for water supply. This is a particular feature in developing countries and zones characterized by abundance of precipitation. ${ }^{2} \mathrm{We}$ argue that the latter may give rise to potential sample selection problems in irrigation choices, which needs to be considered when analyzing the association between production risk and farm technology adoption. For modeling these irrigation choices, we as an example use agricultural census data of potato family farmers in Chile.

Chile has the challenge to transform the Chilean agricultural sector into a worldwide agricultural production and food powerhouse (MINAGRI 2006). However, such a transformation process requires incorporating small holder family farmers into productive agricultural units not only serving themselves (home-production) but as integrated highly productive active agents contributing to the achievement of this objective. The Agricultural Development Institute (ADI) has continually provided technical support to the family agriculture in areas such as investment in human and productive capital, credit provision, access to markets, recuperation of eroded soil and irrigation. In spite of this effort and progress observed in the last decade, the technological gap between large and small-scale farmers persists. For example, $89 \%$ of total land under modern irrigation systems is held by larger farmers (FAO 2009). This fact is what motivates this study to analyze the factors explaining the slow adoption process among small-scale farmers, where the main focus is on the importance of differences in production risk faced by small versus large farmers.

\footnotetext{
1 Too much water poured on the ground by traditional irrigation systems may provoke a saturation process, making excess water flow over the land along with pollutants derived from the remains of pesticides and fertilizers.

${ }^{2}$ In the context of locations suffering from water scarcity, conflicting water use and insufficient levels of investment in water supply infrastructure, the adoption of water-saving technologies arises as one alternative to increase efficiency in water use and minimize contamination problems. Furthermore, watersaving technologies contributes to enhance productivity and quality of production through a more uniform and precise irrigation (Dinar and Zilberman 1991; Khana and Zilberman 1997; Zilberman et al. 1997).
} 
The association between production risk and adoption of modern irrigation is quite straight forward. Risk-averse farmers may not adopt modern irrigation if it raises production risk by increasing yield variability too much. In contrast, if the new technology has the potential to attenuate variability in economic outcomes, then it would be more rapidly adopted among risk-averse small scale farmers. Even though literature on adoption of modern irrigation technology is well-documented, there is little evidence concerning production risk and irrigation choices. Two exceptions are Koundouri et al. (2006) and Torkamani and Shajari (2008). Both studies find support of a positive and significant effect of production risk on adoption decisions, arguing that new irrigation technology is a risk-decreasing input. However, both studies were carried out in settings where the knowledge of irrigation benefits is well-known and the new technology seems to show some degree of consolidation, which only allow to model changes from traditional to modern irrigation systems.

In Chile the pre-conditions are different. Due to abundance of precipitation mainly in the southern territories in Chile, around $83 \%$ of potato farmers do not use irrigation, which amounts to $66 \%$ of registered farming land. Exploiting these differences in natural pre-conditions, we follow Foudi and Erdlenbruch (2012) applying a sample selection approach to study the risk-decreasing properties of irrigation under joint estimation of production and production risk. However, to our knowledge, no previous studies have extended this approach to the decision of shifting from conventional farming to modern irrigation technologies.

Moreover, in light of the high drought risk observed in Chile understanding the underlying mechanisms of irrigation adoption is of fundamental value. Historically droughts are frequent and affect $25 \%$ of the continental territory. Furthermore, climate change studies estimate an intensification of aridity in the north zone, advances of the desert toward the south, and less precipitation in the central zone at the end of the 21st century (FAO 2010). Thus, the augment in temperature and decline in precipitation along with an increasing demand for water resources foresee a higher drought risk for the next decades. Therefore, improvements in water efficiency by the adoption of modern technology are likely to become essential to reduce the vulnerability of agriculture in the future.

The rest of the article is organized as follows: Sect. 2 reviews the main arguments enhanced by literature as determinants of technology adoption. Section 3 describes the empirical strategy and data used to carry out this study. Section 4 presents the main results, and Sect. 5 concludes the article.

\section{Conceptual framework on adoption of new technology}

There is an extensive literature aimed at explaining the process of technology adoption. ${ }^{3}$ Lower adoption rates are generally associated with imperfections in credit markets, information, agro-ecological characteristics, input and output markets as

\footnotetext{
3 The determinants of modern irrigation have been examined by Caswell and Zilberman (1985), Negri and Brooks (1990), Shrestha and Gopalakrishnan (1993), Green et al. (1996), Skaggs (2001), Foltz (2003), Daberkow and Mcbride (2003), Negri et al. (2005), He et al. (2007), Schuck et al. (2005).
} 
well as inadequate incentives associated with farm tenure arrangements, problems mainly observed in developing countries (Feder et al.1985; Bardhan and Udry 1999).

A key element relates to the reduced credit opportunities farmers face. Lack of access to credit in rural areas arises as a consequence of asymmetric information and enforcement problems in the lender-borrower relation. This is particularly augmented among small farmers in developing countries due to the lack of sufficient collateral (Udry 1994). Thus, when innovations require significant levels of investment, credit constraints may turn out to be a limiting factor in adoption decisions. In addition, as the diffusion of innovation is scarce and fails to reach potential users, farmers may face trouble in obtaining the maximum benefit from shifting to modern technologies. The optimal use of new production methods involves adoption of new technologies to the local conditions, which implies a costly learning process (Foster and Rosenzweig 1995). Imperfect knowledge about the usage of new technology constitutes a barrier that delays the adoption process. Furthermore, it is expected that new technologies are more likely to be adopted in rural zones with better support infrastructure and localized near main commercial centers, in which the availability of both complementary inputs and maintenance services are more abundant (Sunding and Zilberman 2001). In addition, tenurial arrangements that characterize the landlord-tenant relationship and land rent contracts can affect adoption decisions. For instance, small farmers without land of their own and facing short-term land contracts are less probable to adopt innovations since they may be unable to enjoy the long-term benefits of doing so (Bahduri 1973). Finally, agro-ecological characteristics that capture environmental heterogeneity are essential to attain a better understanding of the process of adopting sustainable agricultural technologies (Dinar and Yaron 1990; Lee 2005). In particular, modern irrigation methods have a higher relative advantage in zones with lower land quality which lower water-holding capacity (Caswell and Zilberman 1986; Dinar and Zilberman 1991).

In relation to household characteristics, variables that control for differences in farm size, off-farm opportunities, human capital, and gender play an important role to capture the intra-household dynamic in explaining adoption levels (Doss 2006). One key factor less explored in literature is the role of risk in adopting new technology (Foster and Rosenzweig 2010). Rural households must deal with highincome fluctuations as exposed to a variety of uncontrollable factors such as climate conditions, economic fluctuations, policy uncertainty, and individual-specific shock $^{4}$ (Bardhan and Udry 1999; Dercon 2002). In this context, decision making under uncertainty is characterized by risk because some possible outcomes have an undesired effect. If we assume farmers are risk averse, they would adjust their

\footnotetext{
${ }^{4}$ First, climatic risk may trigger harvest failure as a result of occurrences of unexpected events from nature such as drought, flood or frost. Second, the inherent volatility of the agricultural market explained mainly by fluctuations in demand and supply generates another source of income variation via price uncertainty. Third, given the fact that farmers make most decisions in advance far before the final product is sold in the market, prices are not known at the time choices regarding the production process are made. Fourth, the recurrent need that governments face to change the direction of agricultural policy produces a further risk component that enhances the uncertainty in investment decisions. Fifth, individual shock may arise, for instance, when households are hit by an illness or unexpected death of one of its members whose contribution to the family budget is vital.
} 
behavior implementing actions aimed at smoothing income and/or consumption (Dercon 2002). However, when credit and insurance markets are absent or incomplete, poor farmers characterized by limited landholdings, few assets, and lower schooling face serious constraints to smooth consumption. ${ }^{5}$ Consequently, it is expected that farmers depend on ex-ante management strategies to smooth income, which would imply preferences for traditional technology with lower expected returns. It may be true for new irrigation methods that due to higher exigencies of knowledge in its use, adoption would raise the likelihood of failure in spite of higher expected benefits. However, modern irrigation technology is also recognized for being a risk-decreasing input when reducing dependence on rainfall and water availability, which make yields more stable. Koundouri et al. (2006) and Torkamani and Shajari (2008) found a positive effect of production risk on switching from traditional to modern irrigation technology, supporting a riskdecreasing effect.

\section{Agricultural sector and family farming in Chile}

In this paper, we examine the effect of production risk on irrigation choices, focusing on a sample of family farmers in Chile among which modern irrigation is an incipient agricultural practice. The agricultural sector is important in Chile, accounting for $3.5 \%$ of the Gross Domestic Product (GDP) and employing around $12 \%$ of the country's labor force. More than $50 \%$ of production is commercialized in international markets, which makes the sector highly dependent on world market prices. The sector benefits from huge climate diversity, which allows an ample range of cropping activities. This agro-ecological diversity is considered one of the Chile's main comparative advantages. Some major agriculture products consist of fruits, including grapes, apples, pears, peaches, and berries; horticulture, including garlic, onions, and asparagus; and cereal and tuber such as wheat, maize, and potatoes.

Family agricultural production represents one-third of Agricultural Gross Domestic Product (AGDP) and contributes with $1.2 \%$ of the GDP in Chile. In addition, this segment controls $85 \%$ of the farms in the country, and generates 60,000 direct and indirect jobs, benefiting 1.2 million of people. Furthermore, family agricultural producers are one of the main food suppliers in the country, providing around $60 \%$ of food consumed in the domestic markets (INDAP 2011). Family farmers are characterized by being mainly involved in traditional farming activities such as annual crops, horticulture, and extensive cattle farming. They operate small plots at low levels of working capital and often face credit constraints. For simplification, the Ministry of Agriculture defines family farmers as those holding 12 hectares or less of basic irrigation (HBI) (FAO 2009). We follow this definition in this paper.

\footnotetext{
5 Alternatively, poor farmers get involved in informal risk-coping mechanisms based on agreements made by members of the same group or community to support each other in the case of shocks. In addition, farmers also cope with risk by generating incomes from off-farm activities or by receiving remittances from relatives that are in a better position
} 


\section{Data}

This study uses data from the VII National Agriculture and Forestry Census carried out in Chile (INE 2007). ${ }^{6}$ All data is at the household level, except for tenancy status, which was collected at the plot level. Household level data is combined with location level data for soil and climate characteristics.

The Census only reports information on output and input variables for annual crops. Farmers involved in other economically relevant cropping activities, such as fruit trees and horticulture, were unfortunately not asked to report production and input volumes. Given that our framework relies on the estimation of the production function to compute risk measures, our data is not suitable to investigate the association between irrigation technology and production risk to a larger segment of Chile's agricultural sector, other than farms growing annual crops. In spite of the limitations outlined above, census data allow us to deal with a recurring problem observed in site-specific data, in which a few villages or areas are surveyed, and data lack sufficient variation capturing the agricultural potential (Doss 2006). The Census gives us an exceptional opportunity to exploit the climate diversity that characterizes the Chilean territory. Due to its unusual length and the diversity of its landscapes and ecosystems, Chile has many distinct climates, ranging from desert to frosty polar in the extreme south. A national coverage of the Census running more than $4000 \mathrm{~km}$ from north to south guarantees a unique setting to study the role of natural pre-conditions (rainfall and soil characteristics) in the identification of selection into irrigation.

We choose to focus on potato farming. The choice of this crop relies on the economic and social importance for agricultural income-dependent farmers. This crop is the third more relevant annual crop in term of surface and occupies the second position when production value is taken into account. Apart from its economic relevance, potato farming is important from a social perspective due to the fact that it demands great amounts of labor mainly during harvest season, which is particularly transcendental in those zones with higher unemployment. Moreover, this crop extends across the whole territory and its distribution can clearly be organized in agro-climatic zones well differentiated (INIA 2006). This feature allows us to pick up agricultural potential with more precision. Another issue is that we are not able to distinguish amounts of inputs per crop. Thus, to ensure a clean association between observed inputs and potato production, we decided to focus on the sample of potato farmers whose entire land is allocated to this crop. This resulted in a sample of 7274 observations.

Farmers report number of hectares irrigated by different irrigation systems. We aggregate this information into three irrigation statuses: non-irrigation, traditional

\footnotetext{
6 The Agricultural and Forestry Census is conducted each 10 years. The previous Census was carried out in 1997. To our knowledge, the 2007 Census was not designed to be able to track a sub-sample of rural households from previous waves. The latter does not allow us to conduct differences in differences techniques while controlling for unobserved time-invariant effects. However, it is highly likely that structural changes affecting differently irrigators and non-irrigators have taken place in such a long period, which would make difference in difference methods somehow problematic.
} 
Table 1 Number of farmers and hectares per irrigation category

Source: Own elaboration based on Censual data, 2007

a Traditional irrigation does not add up $100 \%$ because some farmers adopt more than one irrigation system. Moreover, some farmers use both traditional and modern irrigation. In this case, they are defined as modern irrigators

\begin{tabular}{lrrll}
\hline Category & \multicolumn{1}{c}{$N^{\circ}$} & $\%^{\mathrm{a}}$ & Hectares & $\%$ Hectares \\
\hline No-irrigation & 6083 & 83.0 & 4094 & 65.6 \\
Irrigation & 1245 & 17.0 & 2146.1 & 34.4 \\
$\quad$ Traditional & 1175 & 94.4 & 1852.5 & 86.3 \\
$\quad$ Flood & 417 & 35.5 & 692 & 37.4 \\
Furrow & 831 & 70.7 & 1139 & 61.5 \\
Other & 17 & 1.4 & 21.5 & 1.2 \\
Modern & 70 & 5.6 & 293.6 & 13.7 \\
$\quad$ Sprinkler & 53 & 75.7 & 215 & 73.2 \\
Center pivot & 2 & 2.9 & 64 & 21.8 \\
Drip & 8 & 11.4 & 6.6 & 2.2 \\
Micro sprinkler & 7 & 10.0 & 8 & 2.7 \\
\hline
\end{tabular}

irrigation and modern irrigation. ${ }^{7}$ Table 1 shows the number of farmers and hectares that fall into each category of irrigation.

The figures show that $17 \%$ of farmers (and $34.4 \%$ of farmed land) use some system of irrigation. In addition, modern irrigation is adopted by $5.6 \%$ of irrigators, covering $13.7 \%$ of the total irrigated hectares. Regarding traditional irrigation, farmers using furrow technology amount to $70.7 \%$ of the total (and $61.5 \%$ as measured by irrigated hectares). On the other hand, sprinkler technology seems to be the more broadly used system among modern irrigators since three out of four adopt this method. Table 2 depicts the summary statistics for inputs, environmental, and location variables by irrigation category. Table 3 shows descriptive statistics for farmers' characteristics and institutional aspects by irrigation category.

Production yield increases as irrigation becomes more sophisticated. The same is true for cultivated area, indicating that irrigation is more likely to be adopted by large farmers. Irrigators mostly reside in zones with lower levels of precipitation. In particular, both modern and traditional irrigators predominate in the central zone. Conversely, non-irrigators are mainly located in southern locations, which experience the highest levels of rainfall.

Education seems to be important to explain adoption of modern technology. Furthermore, modern irrigators seem more agricultural income-dependent than farmers using traditional irrigation. In addition, only $28.5 \%$ of farmers report to have used credit instruments. In relation to extension services, $38.6 \%$ of farmers with improved irrigation methods state to have received extension services in the last 2 years, which compares to the 8 and $16 \%$ observed among traditional irrigators and non-irrigators, respectively. There is a clear trend for irrigators to participate in organizations. Whereas participation reaches around $30 \%$ among irrigated farms, this figure is only $15 \%$ among non-irrigators. Regarding land property status, owning land with a registered title and rented land is more likely among irrigators. While this amount is around $90 \%$ of total land among irrigated farms, it constitutes only $34.6 \%$ of land held by non-irrigators.

\footnotetext{
7 Eleven farmers report to have both traditional and modern irrigation. Given the reduced number of modern irrigators in our sample, we define them as adopting modern irrigation.
} 


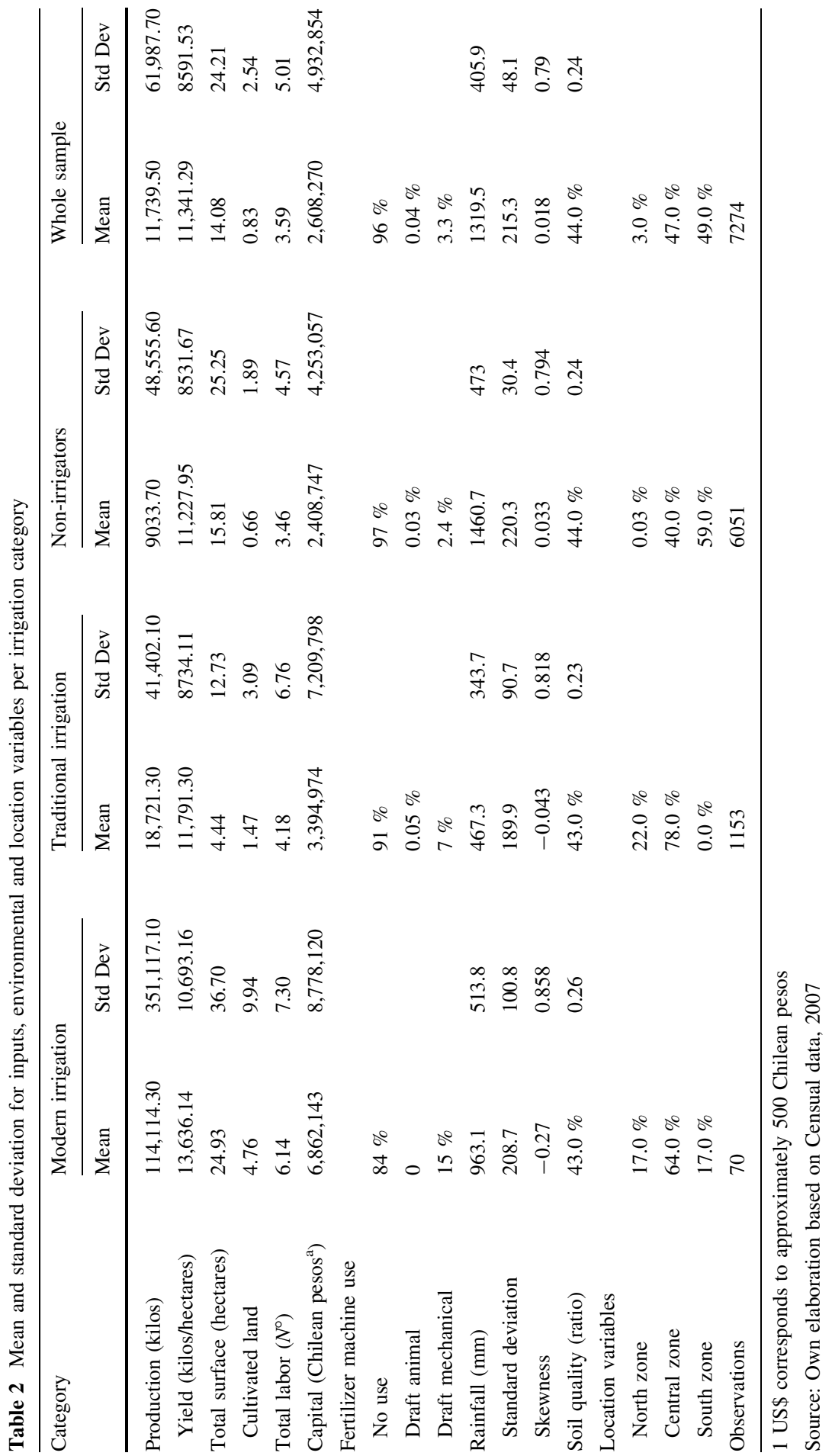


Table 3 Farmers' and institutional characteristics per irrigation category

\begin{tabular}{|c|c|c|c|c|c|c|c|c|}
\hline \multirow[t]{2}{*}{ Category } & \multicolumn{2}{|c|}{ Modern irrigation } & \multicolumn{2}{|c|}{$\begin{array}{l}\text { Traditional } \\
\text { irrigation }\end{array}$} & \multicolumn{2}{|c|}{ Non-irrigators } & \multicolumn{2}{|c|}{ Whole simple } \\
\hline & $N^{\circ}$ & Mean & $N^{\circ}$ & Mean & $N^{\circ}$ & Mean & $N^{\circ}$ & Mean \\
\hline Age & - & 54.44 & - & 55.03 & - & 56.36 & - & 56.13 \\
\hline Male & 55 & $79.0 \%$ & 876 & $76.0 \%$ & 4236 & $70.0 \%$ & 5165 & $71.0 \%$ \\
\hline Reside in plot & 54 & $77.0 \%$ & 657 & $57.0 \%$ & 4780 & $79.0 \%$ & 5528 & $76.0 \%$ \\
\hline \multicolumn{9}{|l|}{ Education } \\
\hline No education & 2 & $2.9 \%$ & 67 & $5.80 \%$ & 163 & $2.70 \%$ & 233 & $3.20 \%$ \\
\hline $\begin{array}{l}\text { Incomplete } \\
\text { elementary }\end{array}$ & 29 & $41.4 \%$ & 548 & $47.50 \%$ & 3685 & $60.90 \%$ & 4263 & $58.60 \%$ \\
\hline $\begin{array}{l}\text { Complete } \\
\text { elementary }\end{array}$ & 8 & $11.4 \%$ & 209 & $18.10 \%$ & 938 & $15.50 \%$ & 1157 & $15.90 \%$ \\
\hline $\begin{array}{l}\text { Incomplete } \\
\text { secondary }\end{array}$ & 9 & $12.9 \%$ & 90 & $7.80 \%$ & 411 & $6.80 \%$ & 516 & $7.10 \%$ \\
\hline $\begin{array}{l}\text { Complete } \\
\text { secondary }\end{array}$ & 6 & $8.6 \%$ & 122 & $10.60 \%$ & 381 & $6.30 \%$ & 509 & $7 \%$ \\
\hline $\begin{array}{r}\text { Incomplete } \\
\text { technical }\end{array}$ & 0 & $0.0 \%$ & 6 & $0.50 \%$ & 24 & $0.40 \%$ & 29 & $0.40 \%$ \\
\hline $\begin{array}{l}\text { Complete } \\
\text { technical }\end{array}$ & 11 & $15.7 \%$ & 55 & $4.80 \%$ & 248 & $4.10 \%$ & 313 & $4.30 \%$ \\
\hline $\begin{array}{l}\text { Incomplete } \\
\text { college }\end{array}$ & 1 & $1.4 \%$ & 12 & $1 \%$ & 48 & $0.80 \%$ & 58 & $0.80 \%$ \\
\hline $\begin{array}{c}\text { Complete } \\
\text { college }\end{array}$ & 4 & $5.7 \%$ & 44 & $3.80 \%$ & 151 & $2.50 \%$ & 196 & $2.70 \%$ \\
\hline \multicolumn{9}{|l|}{ Dependence } \\
\hline$>75$ & 25 & $35.7 \%$ & 205 & $17.80 \%$ & 1355 & $22.40 \%$ & 1586 & $21.80 \%$ \\
\hline$>50$ and $<75$ & 12 & $17.1 \%$ & 98 & $8.50 \%$ & 714 & $11.80 \%$ & 829 & $11.40 \%$ \\
\hline$>25$ and $<50$ & 13 & $18.6 \%$ & 186 & $16.10 \%$ & 1222 & $20.20 \%$ & 1426 & $19.60 \%$ \\
\hline$<25$ & 20 & $28.6 \%$ & 664 & $57.60 \%$ & 2753 & $45.50 \%$ & 3433 & $47.20 \%$ \\
\hline Credit & 43 & $61.40 \%$ & 224 & $19.40 \%$ & 1767 & $29.20 \%$ & 2073 & $28.50 \%$ \\
\hline \multicolumn{9}{|c|}{ Secure tenure (hectares) } \\
\hline $\begin{array}{l}\text { Own with } \\
\text { registered } \\
\text { title }\end{array}$ & 1391.5 & $73.6 \%$ & 24034.8 & $67.6 \%$ & $68,787.3$ & $31.8 \%$ & $94,213.6$ & $37.1 \%$ \\
\hline Rented & 305.5 & $16.2 \%$ & 7625.5 & $21.4 \%$ & 6004.6 & $2.8 \%$ & $13,935.6$ & $5.5 \%$ \\
\hline Occupied & 18.1 & $1.0 \%$ & 10.5 & $0.0 \%$ & $64,069.9$ & $29.6 \%$ & $64,098.5$ & $25.2 \%$ \\
\hline Other & 174.6 & $9.20 \%$ & 3884.4 & $11.00 \%$ & $77,717.9$ & $35.90 \%$ & $81,776.9$ & $32.20 \%$ \\
\hline $\begin{array}{r}\text { Extension } \\
\text { services }\end{array}$ & 27 & $38.60 \%$ & 92 & $8 \%$ & 974 & $16.10 \%$ & 1091 & $15 \%$ \\
\hline $\begin{array}{c}\text { Participation in } \\
\text { organizations }\end{array}$ & 22 & $31.40 \%$ & 351 & $30.40 \%$ & 914 & $15.10 \%$ & 1287 & $17.70 \%$ \\
\hline $\begin{array}{l}\text { Average number } \\
\text { per locality }\end{array}$ & - & 76 & - & 321 & - & 546 & - & 945 \\
\hline Observations & 70 & & 1153 & & 6051 & & 7274 & \\
\hline
\end{tabular}

Source: Own elaboration based on Censual data, 2007 
Table 4 shows the number and percentage of farmers per water source and irrigation category, and Table 5 explores changes in water rights uses across water sources and type of irrigation, respectively.

Up to $44 \%$ of non-irrigators report to have wells as water source in the plot. Differences in costs associated with water extraction between surface and ground water sources naturally impose a restriction to adopt irrigation. However, these restrictions seem to be less important for the adoption of modern irrigation. Wasting water becomes much more costly when pumped from ground water sources ${ }^{8}$ and the availability of water sources other than rivers may promote adoption of new technology (Caswell and Zilberman 1986).

Around $85 \%$ of water sources held by non-irrigators fall into categories classified as insecure tenancy - title is in process of regularization or use de factoin contrast to that observed in both modern and traditional irrigation. Undoubtedly, usage rights are crucial to create correct incentives to undergo innovations that require time to become profitable.

\section{Estimation procedure}

The procedure to analyze the effect of production risk on adoption decisions follows two steps. In the first stage, we estimate the moments of a production function to proxy production risk. In the second stage, the estimated moments are incorporated to explain adoption of modern irrigation in discrete choice models.

\subsection{Production risk}

The moments of the production distribution are estimated by following a sequential procedure in which production is regressed against a set of inputs (Antle 1983; Antle 1987). ${ }^{9}$ The model is specified as follows. ${ }^{10}$

$$
y_{i}=f\left(x_{i}, z_{i}, h_{j} ; \beta\right)+\varepsilon_{i},
$$

where $i=1 \ldots N$ denotes individual farmers, $y_{i}$ is the logarithm of output (potatoes) measured in kilos, $x_{i}$ is a vector of conventional inputs including land, labor, capital, and fertilizer. Land is measured in hectares, ${ }^{11}$ labor is the sum of both family and hired labor, and capital is the value of physical assets. ${ }^{12}$ All these variables are

\footnotetext{
${ }^{8}$ If we assume that the marginal cost of water is closely associated with the energy cost of pumping water, there is a positive relation between depth of water sources and extraction costs.

9 Due to lack of data on prices, we proxy production risk by the moments of production function rather than the moments of the profit function as Koundouri et al. (2006) do. This assumption lies in the linear relationship between the moments of profit and production function valid under price-taker individuals.

${ }^{10}$ We used a Translog functional form which assumes inputs in levels, squares and cross variables.

11 hectares $=2.5$ acres

12 The capital variable was built using information with respect to ownership of draft mechanical capital. These were weighted considering market prices. For the construction of the capital variable, we considered the following tools and machinery: Ploughs trucks, vans, carts, choppers, harvesters, cultivators, zero tillage, spray machines, harrows, rakes, reapers, seeders, hoppers, and tractors.
} 
Table 4 Number and percentage of farmers per water source and irrigation category

\begin{tabular}{|c|c|c|c|c|c|c|c|c|}
\hline \multirow[t]{2}{*}{ Water Source } & \multicolumn{2}{|c|}{$\begin{array}{l}\text { Modern } \\
\text { irrigation }\end{array}$} & \multicolumn{2}{|c|}{$\begin{array}{l}\text { Traditional } \\
\text { irrigation }\end{array}$} & \multicolumn{2}{|c|}{$\begin{array}{l}\text { Non- } \\
\text { irrigators }\end{array}$} & \multicolumn{2}{|c|}{$\begin{array}{l}\text { Whole } \\
\text { simple }\end{array}$} \\
\hline & $N^{\circ}$ & $\%^{\mathrm{a}}$ & $N^{\circ}$ & $\%^{\mathrm{a}}$ & $N^{\circ}$ & $\%^{\mathrm{a}}$ & $N^{\circ}$ & $\%^{\mathrm{a}}$ \\
\hline Well & 17 & 24.3 & 105 & 8.9 & 57 & 44.9 & 179 & 13.0 \\
\hline Spring & 16 & 22.9 & 118 & 10.0 & 33 & 26.0 & 167 & 12.2 \\
\hline River & 25 & 35.7 & 625 & 53.2 & 19 & 15.0 & 669 & 48.8 \\
\hline Stream & 8 & 11.4 & 184 & 15.7 & 30 & 23.6 & 222 & 16.2 \\
\hline Seasonal regulation reservoir & 1 & 1.4 & 19 & 1.6 & 0 & 0.0 & 20 & 1.5 \\
\hline Yearly regulation reservoir & 2 & 2.9 & 62 & 5.3 & 0 & 0.0 & 64 & 4.7 \\
\hline Lake & 0 & 0.0 & 1 & 0.1 & 0 & 0.0 & 1 & 0.1 \\
\hline Lagoon & 1 & 1.4 & 2 & 0.2 & 0 & 0.0 & 3 & 0.2 \\
\hline Other & 5 & 7.1 & 93 & 7.9 & 8 & 6.3 & 106 & 7.7 \\
\hline
\end{tabular}

Source: Own elaboration based on Censual data, 2007

${ }^{a}$ It does not add up $100 \%$ because some farmers have more than one water source

expressed in logarithms. We proxy the amount of fertilizer by including a categorical variable that takes the value zero (0) if the farmer does not use any fertilizer machine, one (1) if the farmer uses a draft animal fertilizer machine and two (2) if the farmer uses a draft mechanical fertilizer machine. $Z_{i}$ is a vector of farmers' characteristics including age (expressed in logarithm), education ${ }^{13}$ and agricultural dependence. ${ }^{14}$ Additionally, we include variables $\left(h_{j}\right)$ to capture variations in soil quality and rainfall ${ }^{15}$ (expressed in logarithm) in locality $j$ as well as regional differences. Soil quality is measured by the percentage of non-eroded and slightly eroded soil ${ }^{16}$ and rainfall was constructed as the cumulative precipitations in the season 2010-2011. Unobserved regional differences are picked up by including

\footnotetext{
13 It takes the value of 0 if the farmer has no formal education, 1 if $\mathrm{s} /$ he has partially completed elementary school, 2 if s/he has completed elementary education, 3 if s/he has partially completed high school, 4 if s/he graduated from high school, 5 if s/he has partially completed a technical program, 6 if $\mathrm{s} /$ he has completed a technical program, 7 if $\mathrm{s} / \mathrm{he}$ has partially completed her/his university education and 8 if $\mathrm{s} /$ he graduated from college/university.

14 It takes the value 3 if the agricultural income represents $75 \%$ or more of household income, 2 when the proportion is between 50 and $75 \%, 1$ if it is between 25 and $50 \%$ and 0 if this percentage is less than $25 \%$.

15 Rainfall data were obtained from agro-climate information provided by the Chilean Institute of Meteorological Information (CIMI 2011) between the agricultural seasons 1999-2000 and 2005-2006. Climate measures per location were obtained by matching locations with the nearest meteorological stations. Unfortunately, information for regions VIII, IX, X and XIV are not available in the agro-climate yearbooks with the same level of detail as the rest of the zones. For these cases, we used information available in climate yearbooks collected from meteorological stations situated at airports.

16 Information on erosion was used as a proxy for land quality. It was extracted from a recent study conducted by the Center of Information in Natural Resources (CIREN 2010), addressed at determining the current and potential erosion of soils in Chile. The methodology for determining the level of erosion integrates a set of soil, topographic, climatic and biological characteristics. Thus, erosion will be more severe to the extent that soils are more porous and sandier, fields are more sloped and hold less vegetation as well as in those locations where precipitations are more "aggressive".
} 


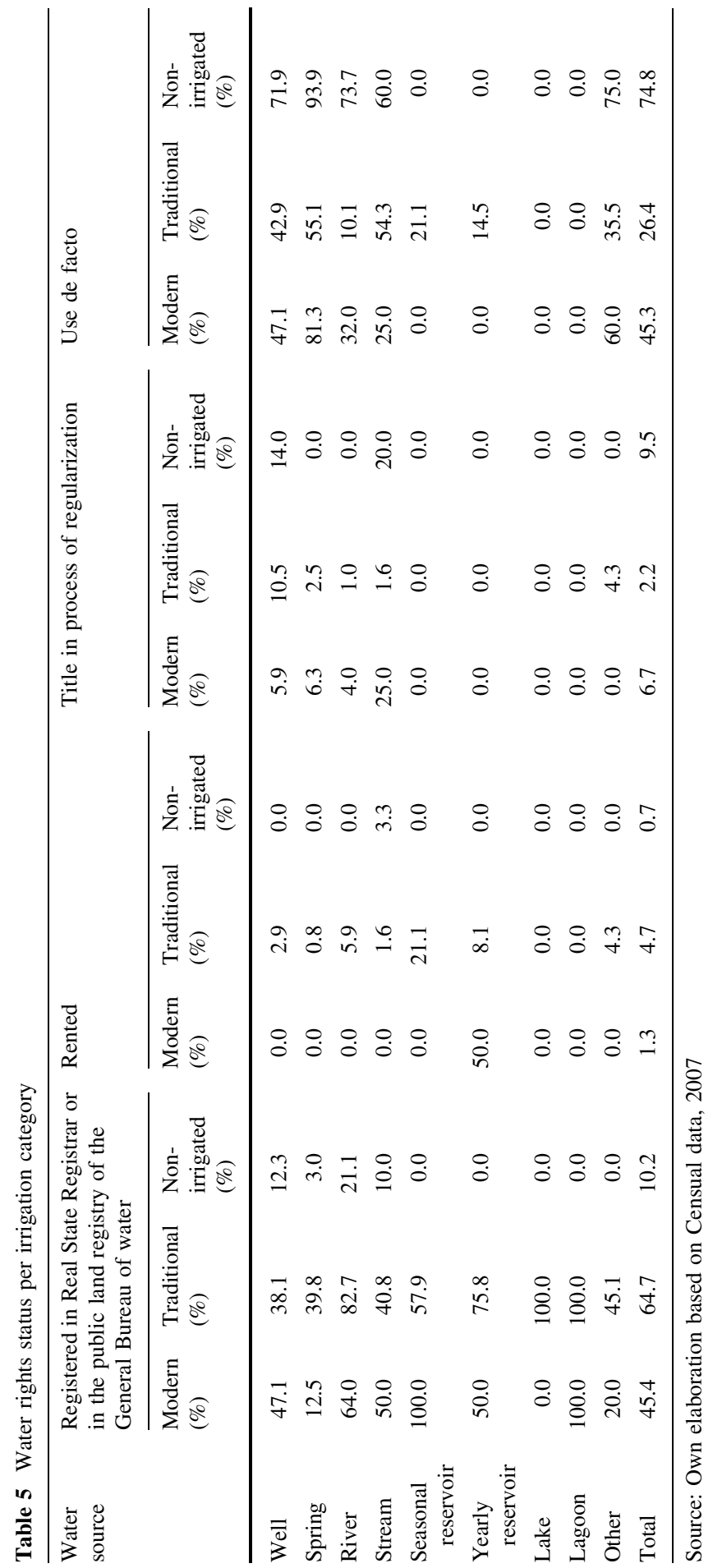


indicator variables for each region. $\varepsilon_{i}$ is the identically and independently distributed (iid) error term.

Under expected profit maximization, explanatory variables are assumed to be exogenous, and thereby ordinary least squares (OLS) of (1) produce consistent and efficient estimates of the parameter vector $\beta$ (Koundouri et al. 2006). The $s$ central moment of production conditioned on inputs about its mean is defined as:

$$
\mu_{\mathrm{s}}(.)=E\left\{\left[y(.)-\mu_{1}\right]^{\mathrm{s}}\right\},
$$

where $\mu_{1}$ denotes the mean of production. Thereby, the estimated errors $\hat{\varepsilon}_{i}=$ $y_{i}-f\left(x_{i}, z_{i}, h_{i} ; \beta\right)$ from (1) are estimates of the first moment of the production distribution. To compute estimates of the second moment, the estimated errors $\hat{\varepsilon}$ are squared and regressed on the same set of inputs as in (1):

$$
\hat{\varepsilon}_{i}^{2}=g\left(x_{i}, z_{i}, h_{i} ; \delta\right)+\bar{\varepsilon}_{i} .
$$

OLS provides consistent estimates of the parameter $\delta$, and the predicted values are consistent estimates of the second moment of production distribution (Antle 1983). Estimation of the third moment follows the same procedure. This approach exploits the use of cross-sectional data assuming that the moments vary among farmers depending on input level, farms' characteristics and environmental conditions. Conditional moments are thereby used as measures of volatility to rank farmers in terms of production risk.

\subsection{Irrigation choices}

In the second stage, the estimated moments are incorporated as explanatory variables in a discrete choice model. Additional control variables include a dummy denoting if the farmer is male; farmers' age measured in years (in log); farmers' level of education; a categorical variable that captures the degree of dependence on agricultural activity; a dummy variable indicating if the farmer lives in the plot; the farm's size measured in total hectares (expressed in a logarithm); capital value of agricultural machinery and tools (expressed in a logarithm); secure tenure measured by the ratio between the sum of family-own hectares and rental land over total hectares; a dummy variable indicating if the farmer had access to credit during the last 2 years; a dummy variable indicating participation in any agricultural organization; a dummy variable denoting if the farmer received extension services during the last 2 years; percentage of non-eroded and slightly eroded soil; number of both modern and traditional adopters per locality regardless of crops; and a set of dummy variables to control for unobserved spatial differences in technology choice across zones.

We propose three alternative models. First, we model irrigation decisions as an ordered choice such that each category corresponds to a superior level of irrigation technology. One may expect a monotonic relationship between risk production measures and specific irrigation technologies as the capability of irrigation methods to reduce production risk increases with the level of technicality. Second, we assume that irrigation choices are unordered at different production risk levels. 
Despite reduction in production risk from shifting from a non-irrigation status to a traditional irrigator seems quite evident, gains from adopting modern irrigation for a former traditional irrigator are more unclear as new technology involves uncertainty. Finally, we discuss potential selection problems when analyzing the shift from traditional to modern irrigation. We argue that the choice and economic benefits of irrigation adoption depend on natural pre-conditions to irrigate. Thus, when considering only irrigation data, we might lose track of some people who are eligible to adopt modern irrigation. If this characteristic is systematic, our standard probit estimation may lead to inconsistent estimates (Wooldridge 2010). We, therefore, also estimate a binary response model with sample selection (Van de Ven et al. 1981) to address this problem. Denoting $Y$ as the irrigation decision observed with the value of 1 if the farmer irrigates and 0 otherwise, the selection equation can be expressed as follows:

$$
\operatorname{Pr}\left[Y_{i}=1\right]=\operatorname{Pr}\left[Y_{i}^{*}>0\right]=\operatorname{Pr}\left[w^{\prime} \varphi+\xi_{i}>0\right]=\operatorname{Pr}\left[\xi_{i}<w_{2}^{\prime} \varphi\right],
$$

where $Y_{i}^{*}$ corresponds to a latent variable that depends on a set of variables $w$, among which we include those to allow for identification of the vector $\varphi$. Basically, we argue that selection into irrigation mainly lies in the fact that despite the presence of water resources in the farm, a significant number of farmers do not make use of these water courses for irrigation. Tables 4 and 5 show that the type of water source and water rights statuses may play a role here. Thus, we assume that irrigation decisions respond to the availability of water sources in the farm and moments of rainfall distribution. We account for water sources by defining a dummy variable that takes the value of 1 if the farm holds at least one source for irrigation.

\section{Results}

Estimation of the selection equation is depicted in Table 6. As expected, accessibility to water sources plays a crucial role in explaining the shift from complete reliance on rainfall to adoption of irrigation systems. Furthermore, farmers who reside in locations with lower levels of precipitation, higher variance, and

Table 6 Estimates of the selection equation

Standard errors in parentheses
Independent variables of the
selection equation are not shown
due to space reasons
$* * * p<0.01, * * p<0.05$
$* p<0.1$

\begin{tabular}{ll}
\hline Variables & $\begin{array}{l}\text { Probit with sample selection } \\
\text { Irrigation }=1\end{array}$ \\
\hline Water source & $4.63(0.39)^{* * *}$ \\
Rainfall & $-0.95(0.16)^{* * *}$ \\
Standard deviation of rainfall & $0.005(0.001)^{* * *}$ \\
Skewness of rainfall & $0.31(0.12)^{* *}$ \\
Athrho & $1.13(0.39)^{* *}$ \\
LR test $(\rho=0)$ & $13.21 * *$ \\
Observations & 7274 \\
\hline
\end{tabular}


skewness are more likely to irrigate. ${ }^{17}$ Similar results were found in related literature before. For example, Negri et al. (2005) examines the independent effects of climatic mean and variance on the probability of adopting irrigation in USA. The authors find that higher temperatures and less rainfall increase irrigation, and most importantly that the tails of precipitation distributions and water availability are primary determinants of presence of irrigation. Furthermore, Foudi and Erdlenbruch (2012) study the role of irrigation as a self-insurance instrument in the management of production risk in France. They find that irrigation decision depends on the decision to purchase yield insurance as well as the mean and variance of water availability. We compute a likelihood ratio test assuming under the null hypothesis $\rho=0$, that is, the log-likelihood for the probit model with the sample selection is equal to the sum of the log-likelihoods of estimating a probit model for modern irrigation and the selection equation separately. The evidence rejects the null hypothesis suggesting that farmers irrigating may not be a random sub-sample of total rural households, which supports the use of data on non-irrigators to correct for sample selection.

We employ a Translog functional form to estimate the parameters of the production function. Results are not shown but can be obtained from the authors upon request. We use these estimates to compute the moments of the production function, which are our proxies for production risk in the irrigation choice models. Table 7 reports the estimated coefficients and standard errors in parenthesis for the irrigation choice models. ${ }^{18}$ The first column shows the estimated coefficients that result from modeling irrigation as a binary variable. Column 2 depicts the estimates for the ordered probit model, which assumes an order in irrigation choice. The third column shows the estimated parameters for the multinomial probit model. We assume non-irrigation status as the baseline. Column 4 shows the estimated coefficients for the model of modern irrigation for the selected sample of irrigators. In this case, non-irrigators were dropped from the sample. Column 5 presents the results for the model of adoption of new technology conditioned on whether a farmer is already an irrigator. Regardless of the approach used, education, capital, extension, credit access, number of adopters, and rainfall are statistically significant to explain adoption of irrigation in general, and modern irrigation in particular. ${ }^{19}$

\footnotetext{
17 A regional analysis based on agro-ecological zones with similar underlying natural conditions can be an alternative manner to account for the initial choice of irrigation. Unfortunately, there is not enough information on the irrigation status to reach convergence in the estimations for agro-ecological zones (no non-irrigators in the north region and very few irrigators in the south). The later suggests that the "nonirrigation" status in some regions may lead to issues of colinearity. Alternatively, we replicate all the estimations considering only those regions where each irrigation status is observed. This implied to drop Regions VI, X and XIV from our sample. Yet, the results remain essentially unchanged. Results are shown in Appendix 1.

18 Due to the inclusion of generated regressors in adoption equations in the form of moments of the production distribution, standard errors were corrected using bootstrapping techniques.

19 Multicollinearity is always a concern. For instance, education is most likely highly correlated with income variables such as the percentage of income coming from agriculture, capital and land can ease access to credit, etc. However, correlation coefficients show of correlations. We obtained a coefficient of 0.16 for land and credit, 0.22 for land and capital and 0.27 for dependence on agriculture and capital. The later indicates that this is not likely to be a major problem in this data. Results available upon request.
} 


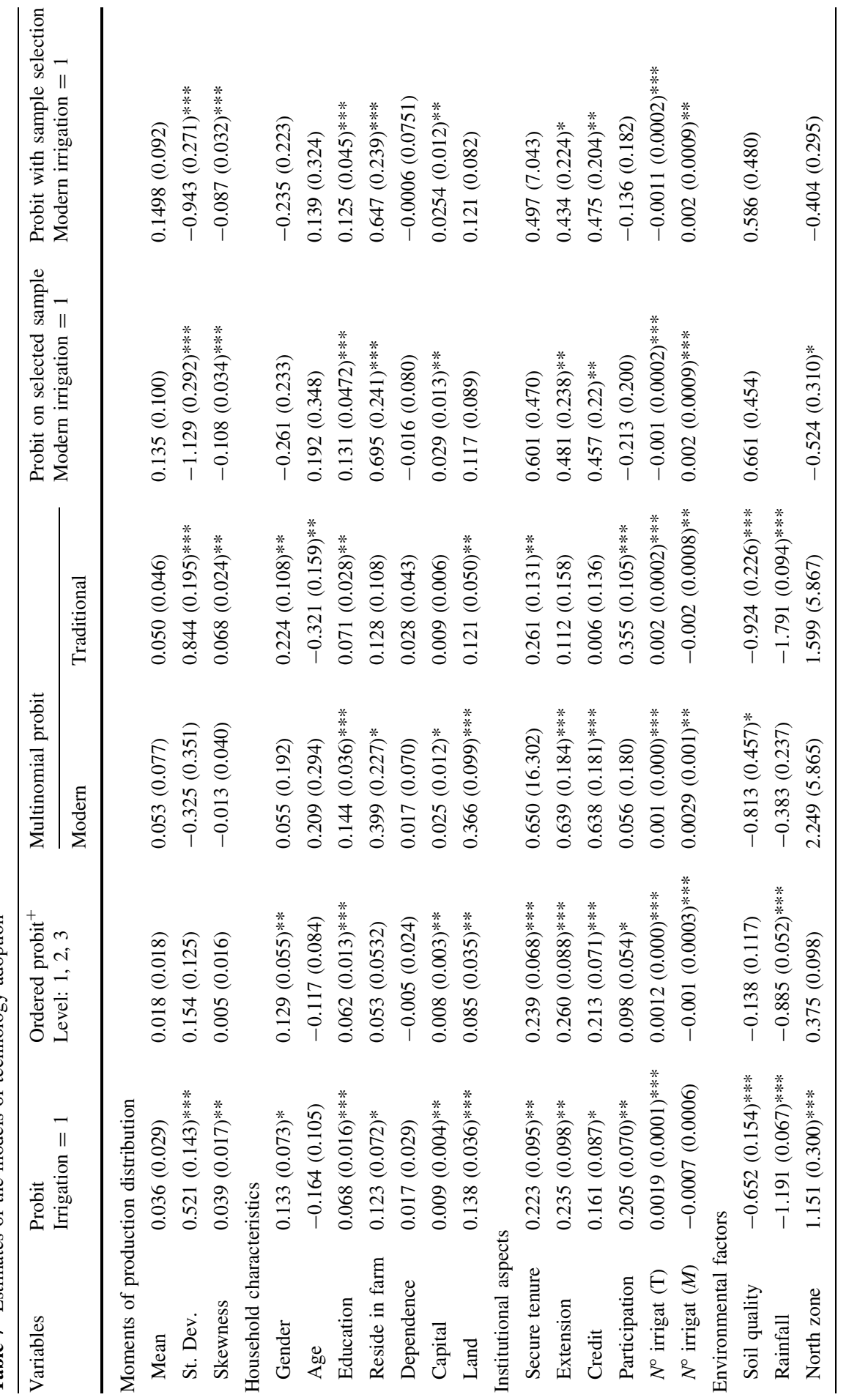




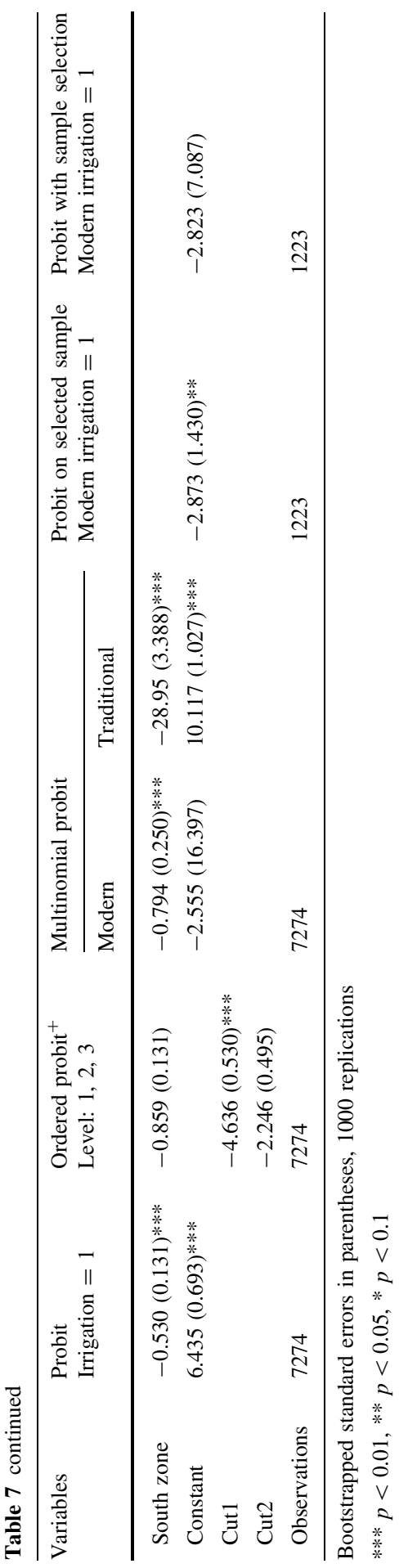


Education, capital, credit, and extension services are positively associated with adoption. Similar results have been found in developing countries in the literature before. For example, He et al. (2007) investigate the determinants of farmers' decisions to adopt rainwater harvesting and supplementary irrigation technology in China, finding that socioeconomic characteristics such as age and education, and institutional factors associated with extension, assistance, training, and credit services affect positively irrigation adoption decisions. Household resource endowment variables, showing the ability of farmers to operate their land, were also found significant in explaining farm irrigation decisions in Ghana (Dessalegn 2005). Results confirm the role of education as a complement to adoption when it is knowledge intensive, and benefits are linked to farmers' management capacity. Furthermore, they enhance the importance of access to credit in decisions that involve financing needs. Finally, the implementation of water-saving technologies demands more knowledge about environmental factors, i.e. evaporation conditions, to reach efficiency in water application, which makes extension services from government agencies be more crucial.

Furthermore, the number of adopters of both traditional and modern irrigation at the local level is also significant. This result is in line with the literature addressing the role of social learning spillover on adoption of new technology among farmers that belong to related networks or adjacent geographical areas. For example, Foster and Rosenzweig (1995) find that neighbors' experience influence rates of adoption and profitability of high-yielding varieties (HYV) in India. The later suggests that farmers involved in a bigger network of experienced farmers with new technology are more likely to adopt the new technology and are relatively more profitable. Furthermore, Conley and Udry (2010) investigate the role of social learning in the diffusion of a new agricultural technology in Ghana. They find support of farmers adjusting their inputs in accordance with those of their neighbors who were surprisingly successful in previous periods. Finally, Bandiera and Rasul (2006) present evidence on how farmers' decisions to adopt a new crop relate to the adoption choices of their network of family and friends in Mozambique. The authors find farmers are more likely to adopt when other farmers in their network also adopt.

When looking at the results from the probit model and ordered probit model (column 1 and column 2, respectively), we also find significant effects of gender, farm size, secure tenure, and participation in organization. Gender differences in technology adoption are discussed in Ndiritu et al. (2014). The authors find a gender gap in the adoption pattern for some farm technologies in Kenya, indicating the existence of certain socioeconomic inequalities and barriers for female farmers. Furthermore, the larger the farm is the more probable adoption of irrigation technology. Just et al. (1980) show that given the information and transactions costs associated with innovations, as these costs increase, the critical size that make the adoption profitable also increases. The latter implies that new technology, which involves larger information/transactions costs are less likely to be adopted by smaller farmers. Empirical works confirm this prediction (Negri and Brooks 1990; Shrestha and Gopalakrishnan 1993; Skaggs 2001; Daberkow and Mcbride 2003; Schuck et al. 2005). 
Farmers that hold a larger ratio of both owned land and land under property rental contracts are more likely to irrigate. Similar results are found in the literature before. For example, Soule et al. (2000) investigate the influence of land tenure on the adoption of conservation practices in US. They find that the owner-operators are more likely to adopt practices that provide benefits over the longer term. Furthermore, Gebremedhin and Swinton (2003) examine the role of land tenure security in investing in soil conservation in northern Ethiopia. They find that adoption of technologies associated with long-term investment such as stone terraces was positively influenced by land tenure security. These findings confirm the importance of designing tenancy arrangements that guarantee rights to enjoy long-term benefits derived from implementing technological innovations.

In addition, results show that farmers participating in agrarian organizations are more likely to use irrigation. Participation in organization may serve as a vehicle for the adaptation, likely because transmission and diffusion of knowledge on new technologies are fostered in organizations. These results are in line with Isham (2002). The author finds that households with ethnically based and participatory social affiliations in Tanzania may be more likely to diffuse new information successfully and therefore to adopt new technologies.

We also explore the interactions between some institutional aspects and household characteristics in our adoption models (see Table 8). In particular, we interact age, education, and farm size with the institutional variables secure tenure, extension, and credit. We find that extension services are more likely to promote adoption of irrigation among smaller farmers. This is important for focalizing extension resources. When studying the switch from non-irrigation to modern irrigation, extension services also play a role here, and access to credit seems to help less educated and small farmers more. The latter suggests that institutional aspects are more important for less favored farmers (small and less educated farmers). We do not find significant results for the interacted variables when studying the switch from traditional to modern irrigation.

There are some discrepancies in the results concerning the variables (1) residence in the farm, (2) soil quality, and (3) production risk measures. Regarding (1), results show that farmers who reside at the farm premises are more likely to adopt irrigation technology. In particular, farmers are more willing to shift from nonirrigation to the new technology, as shown by the multinomial probit, and change from traditional irrigation to new technology, as suggested by the probit model with sample selection. These results may be consistent with information diffusion arguments (Foster and Rosenzweig 1995) Bandiera and Rasul 2006), as interactions and networks associated with farming activities are more likely to happen on-farm.

Moreover, results from the multinomial probit model show that both traditional and modern irrigation are promoted in zones with poorer soil conditions, probably as a means to deal with these disadvantageous characteristics. However, soil quality considerations do not seem to drive shifts from traditional to modern irrigation. Results are in line with previous studies finding that modern irrigation technologies are more likely used in locations with relatively low land quality (Caswell and Zilberman 1986; Dinar and Yaron 1990; Green et al. 1996). 


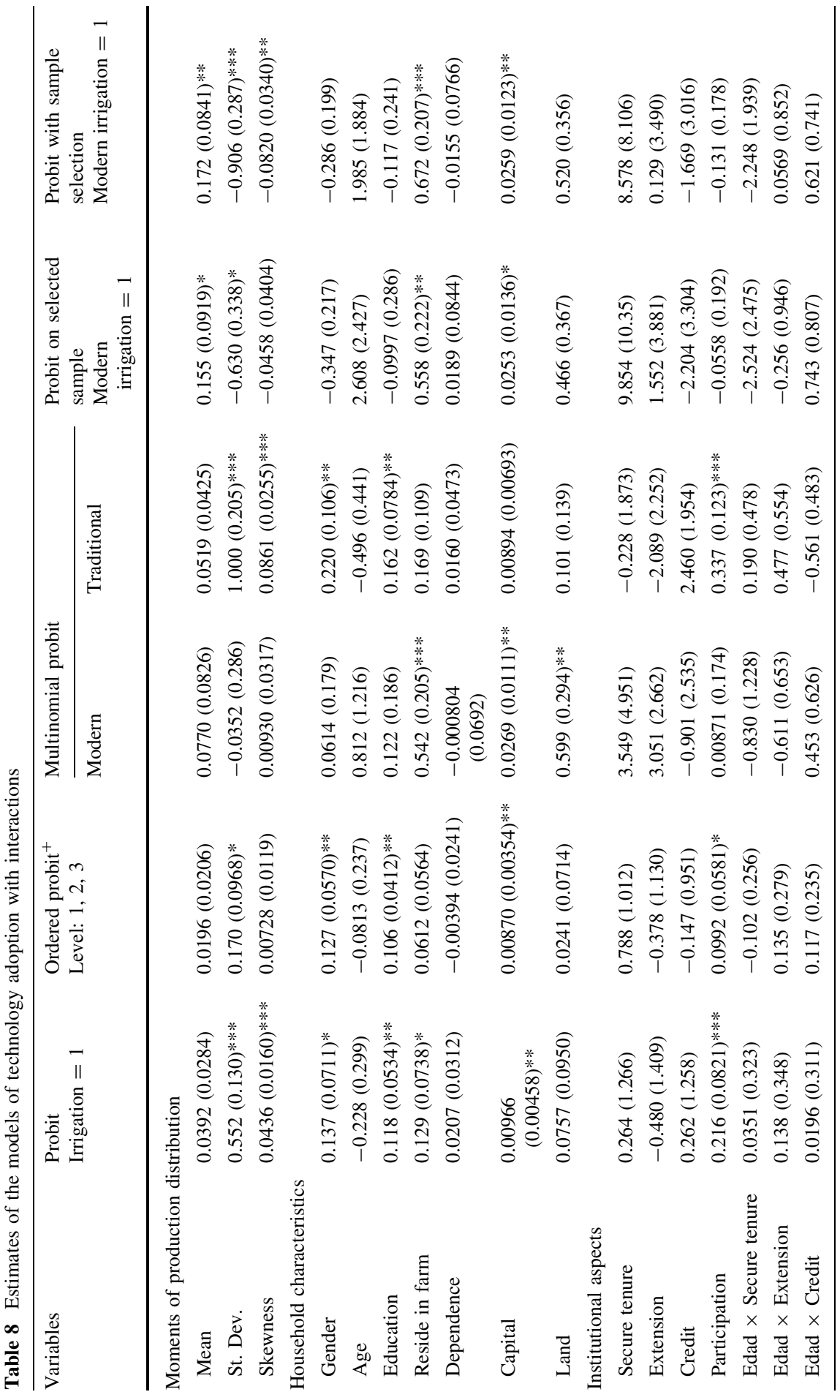




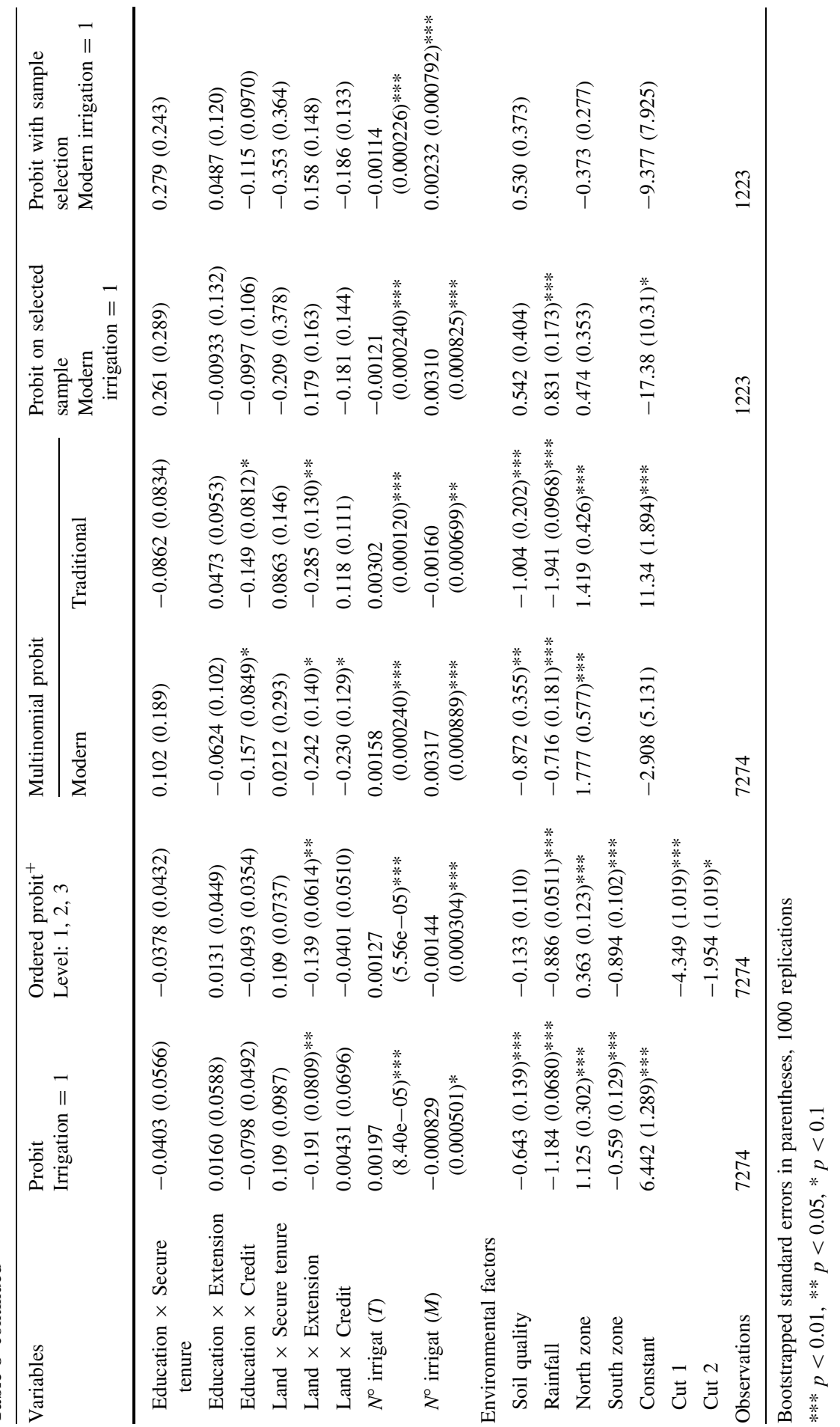


Regarding production risk, results are twofold. On the one hand, production risk positively affects the shift from non-irrigation to adoption of traditional technology. In other words, our findings suggest that the greater the variance of production, the higher the probability farmers will implement traditional irrigation systems. Similarly, a greater value in the skewness of production entails a higher probability of implementing traditional irrigation. This last finding tells us that farmers care about downside yield risk, assigning negative weights to production distribution that show higher probabilities of obtaining lower production values. On the other hand, adoption of modern irrigation responds negatively to increases in both variance and skewness of production when having traditional irrigation as baseline. Results are robust to regional differences (see Appendix 2). ${ }^{20}$ The latter entails that farmers are less willing to shift to modern irrigation when experiencing less certain yields and higher downside risks. While results regarding traditional irrigation support the well-known decreasing-risk properties of irrigation, findings on modern irrigation are not in line with the ability of new technology to hedge against production risk highlighted in the literature before (Koundouri et al. 2006; Torkamani and Shajari 2008).

To verify if these findings can be applicable to larger segment of the Chile's agricultural sector, we conduct a series of robustness checks. First, we replicate our results using information on wheat small-scale farmers. Wheat is one of the most important crops in Chile, comprising more than $50 \%$ of the total hectares devoted to annual crops, and grown in the whole country in diverse climate and soil conditions. To allow enough information in all the irrigation categories, we, here, were less restrictive than in the potato case. We selected those farmers that reported to devote more than $90 \%$ of their hectares to wheat farming. This is an issue in the sense that we cannot guarantee that the inputs observed in the data are indeed used in the wheat production process as in the potato case. This is crucial for estimating production risk measures such that results must be interpreted with caution. Results are shown in Appendix 3. We find similar evidence as in the case of potato farmers. Adoption of traditional irrigation is more likely to occur among farmers with high production risk. However, the risk-reducing effect of modern irrigation technology remains unclear. Second, to gain efficiency, we pool observations of farmers allocating $100 \%$ of land to either potato or wheat. Although the pooling exercise seems to be reasonable, issues regarding the association between inputs and outputs can emerge again when potatoes and wheat are not necessarily grown using the same inputs (or we do not observe that). Results are shown in Appendix 4. We find support for previous findings. Traditional irrigation seems to be risk-decreasing from the perspective of non-irrigators while the switch from traditional to modern irrigation increases production risk. Third, potato and wheat farming are more resilient and less water demanding than other crops such that results regarding the switch from no-irrigation to traditional irrigation (and not modern irrigation) reducing production risk may respond to this specific characteristic. To explore this further, we replicate the results for rice farming, a water-intensive crop. However,

\footnotetext{
${ }^{20}$ Due to the inexistence of modern irrigation observations in some regions, we were not capable to control for all regional dummies in all the specifications.
} 
exactly the same issue emerges as in other similar crops. The rice sector in Chile is small, and it is not spread out the whole territory, which reduces climate variation. The Census reports 1534 rice farmers mainly located in the central-south regions in Chile. The majority of them use traditional irrigation (96\%) and only a small fraction (4\%) modern irrigation. Farmers without irrigation methods amount to $1.56 \%$. Given the structure of irrigation adoption in rice farming, it is not possible to control for pre-conditions applying sample selection models such that decisions narrow down to a switch from traditional to modern irrigation. One caveat is that we cannot ensure that irrigation is associated with rice farming since many of the rice farmers grow jointly other crops. When applying the criterion of $100 \%$ land allocation in rice to ensure association between inputs and rice output, we end up with very few observations (86), of which only one farmer reports to use modern irrigation. The low adoption of modern irrigation among more water intensive crops suggests that the insufficient technification in irrigation is a general problem in the agricultural sector in Chile. Having those data issues in mind, we replicate the results for those farmers that report to grow rice (see Appendix 5). We do not find significant results for the second and/or third moments of the production distribution, although coefficients are negative.

Lack of support of the risk-reducing effect of modern technology may imply that farmers in Chile are facing problems regarding seeing the virtues of water-saving technologies as risk-decreasing inputs, probably due to the higher uncertainty observed in the earlier stages of diffusion. The optimal use of methods of modern irrigation may depend on certain characteristics of soil and climate that are specific to a particular farm and influence the quantities of water required to achieve efficiency in water application. The structure of this relationship may be more difficult to determine in earlier stages. In fact, new irrigation technology in Chile is indeed in an early phase of the technological cycle, where lower levels of knowledge and diffusion may possibly be adding an additional uncertain component that would offset the advantages of modern irrigation. In contrast, when analyzing the adoption of traditional irrigation, we are looking at shifts from a natural state of non-irrigation toward the use of water input. In particular, this technological change seems to be more developed in Chile and has likely reached a phase of maturity in the technological cycle. The latter supports the importance of improving the understanding and modeling of irrigation choices in settings in which rainfed agriculture is still predominant, as typical in developing countries.

Finally, we evaluate the predictive ability of models looking at the percentage of correct predictions. ${ }^{21}$ Appendix 6 shows these results. Percentages of correct predictions range from 87 to $96 \%$, and univariate models explaining modern irrigation choices, having as a baseline traditional irrigation, perform better than multivariate models. Correct predictions as estimating a probit model for modern irrigation choices increases significantly from 1 to $29 \%$. Correcting for sample

\footnotetext{
${ }^{21}$ A prediction is assumed correct when the estimated probabilities of observing a determined irrigation status surpass $50 \%$. Predictions for modern irrigators in the probit model with sample selection were computed using conditional probabilities - that is, probability of success conditional on selection. Furthermore, non-irrigation predictions for this model correspond to those computed using estimates of the selection equation.
} 
selection improves the fitting of the model, adding $14 \%$ extra correct predictions. Furthermore, prediction in all of the remainder irrigation statuses also improves. The latter suggests that modeling non-irrigation as one more level of technology may be inappropriate when there exists specific natural pre-conditions that drive non-irrigation choices. Thus, it seems reasonable to control for these pre-conditions before studying changes from conventional to new irrigation technology.

\section{Conclusion}

New irrigation technology can improve productivity by attaining higher efficiency in water application, which also brings external benefits in the form of water conservation. Furthermore, new irrigation methods hold numerous advantages in zones with limiting environmental conditions, i.e. water scarcity and lower soil quality. In this paper, we study the effect of production risk on the adoption of irrigation. A large fraction of rural households in developing countries does not use either modern or traditional irrigation and is completely exposed to climatic variations. This gives rise to the question on how to include non-irrigators when estimating irrigation choices. We discuss results from an ordered, unordered, and sample selection models.

The results indicate that farmers with a higher educational level, larger capital, credit access, receiving extension services, and those who reside in the plot and in communes with larger number of adopters are more likely to adopt modern irrigation. On the other hand, results for production risk depend on the type of irrigation technology. Whereas production risk promotes adoption of traditional irrigation, it seems to be an obstacle when assessing shifts from traditional to modern irrigation. Credit access, extension services and production variance seem to be more important in terms of magnitude.

However, a couple of caveats deserve attention. First, given the cross-sectional nature of our data, we are not able to fully explore dynamics in irrigation decisions. These may be important, especially in examining the role of economic and policy changes on adoption of modern irrigation. Second, our results may be crop-specific since water needs are supposed to vary across different cropping activities. For example, potato and wheat are relatively more resistant to water stress than other crops such as rice and fruits and therefore a switch from conventional to modern irrigation methods may be more likely to be risk-decreasing in these last cases. Even though we did find sufficient evidence for our sample of rice farmers, data issues do not allow us to state plausibly whether our results can be extrapolated to other relatively more water-demanding cropping activities. Further research examining how results vary across different crops is needed.

Despite these considerations, our findings have important implications for the success of government interventions to address concerns of the low rate of adoption of new irrigation technology. First, adoption of irrigation indeed reduces risk; however, we found that farmers may experience an increase in production risk when switching from traditional to modern irrigation methods. This increased risk may be because of lack of diffusion and knowledge on water-saving technology, which 
make future profit flows much more uncertain, especially in early stages of the technological cycle. The latter prevents the full exploitation of the advantages of modern irrigation in terms of high productivity and lower production volatility. Our results suggest that policy interventions through extension programs providing adoption-related information and easing access to credit are necessary to induce faster adoption and diffusion among small-scale farmers. Second, we found evidence in favor of sample selection correction as analyzing irrigation choices. Therefore, controlling for pre-conditions that determine irrigation before analyzing changes in technology is crucial to achieve a better understanding on irrigation choices in developing countries where non-irrigators still remain as a significant part of the rural population. Finally, another important implication of our empirical findings is that climate change, which is expected to increase temperature and reduce precipitations in Chile, is likely to have a material effect on the agricultural sector. More specifically, it may increase drought risk and therefore reduce crop yields. Thereby, adoption of more efficient irrigation technologies is crucial to manage the higher climate risk expected for the coming years.

Acknowledgements This study was funded by the Research Support Fund, University of Bio-Bio, Project DIUBB 1567172/RS and Project GI 160317/EF. The authors thank valuable comments received at the seminar of the Development Economics Research Group (DERG), Department of Economics and Department of Food and Resource Economics, University of Copenhagen, and Nordic Conference in Development Economics, Gothenburg, Sweden. Special thanks go to Finn Tarp, Benedikte Bjerge and Marcela Jaime for their valuable comments on earlier versions. The article was also improved by helpful comments from anonymous referees and the editor. The usual caveats apply.

Open Access This article is distributed under the terms of the Creative Commons Attribution 4.0 International License (http://creativecommons.org/licenses/by/4.0/), which permits unrestricted use, distribution, and reproduction in any medium, provided you give appropriate credit to the original author(s) and the source, provide a link to the Creative Commons license, and indicate if changes were made.

\section{Appendix 1}

See Table 9. 


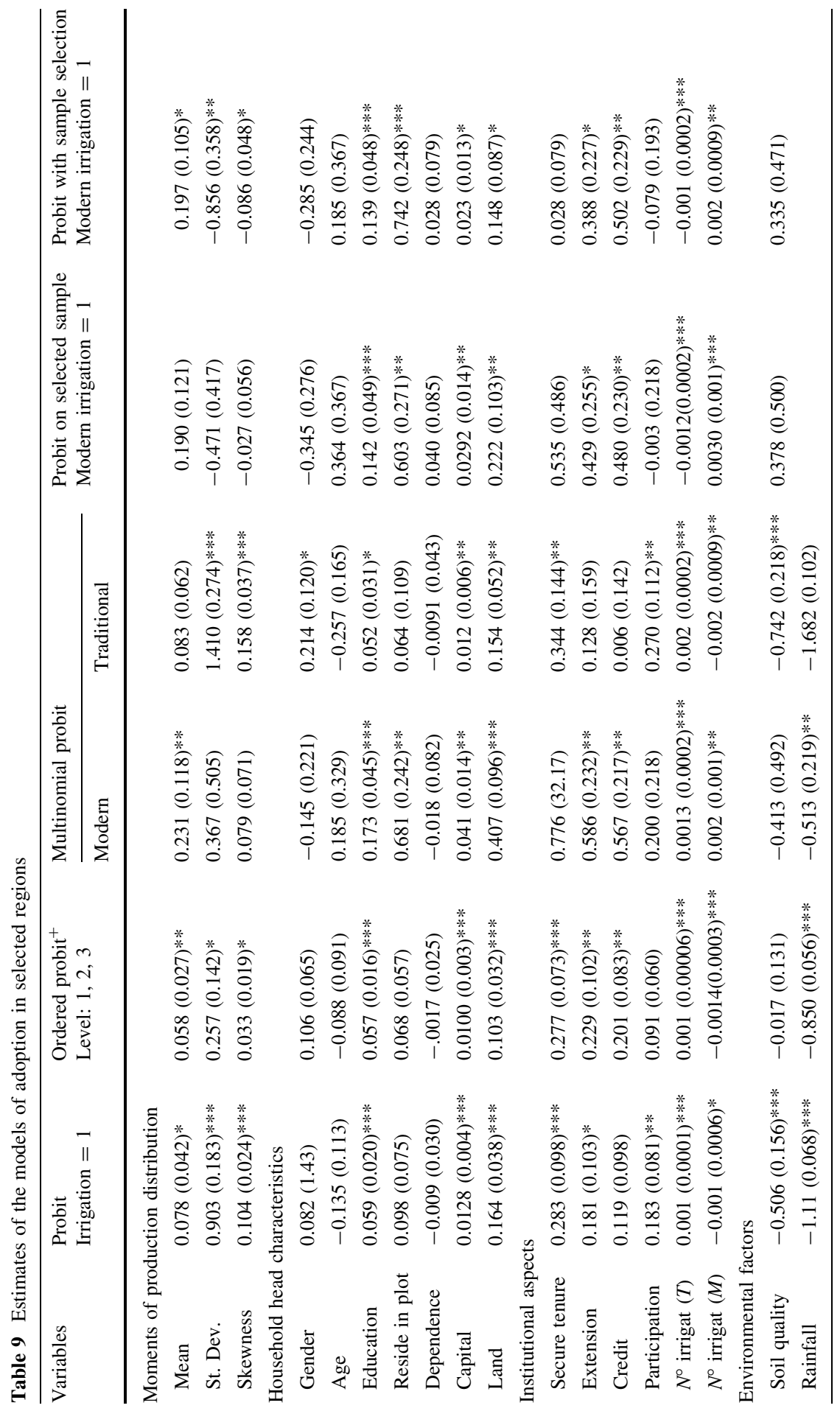




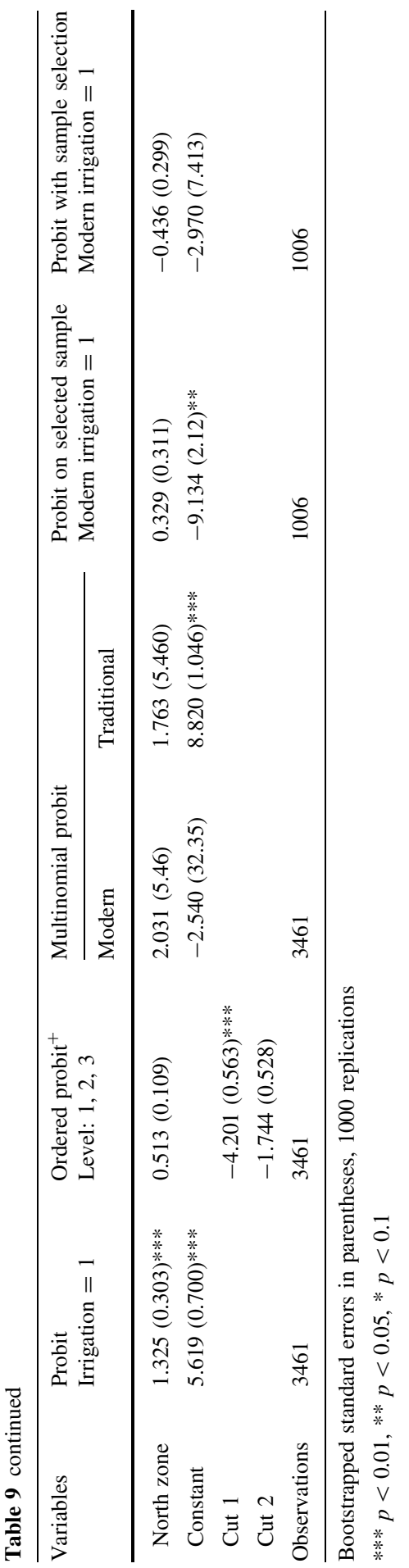




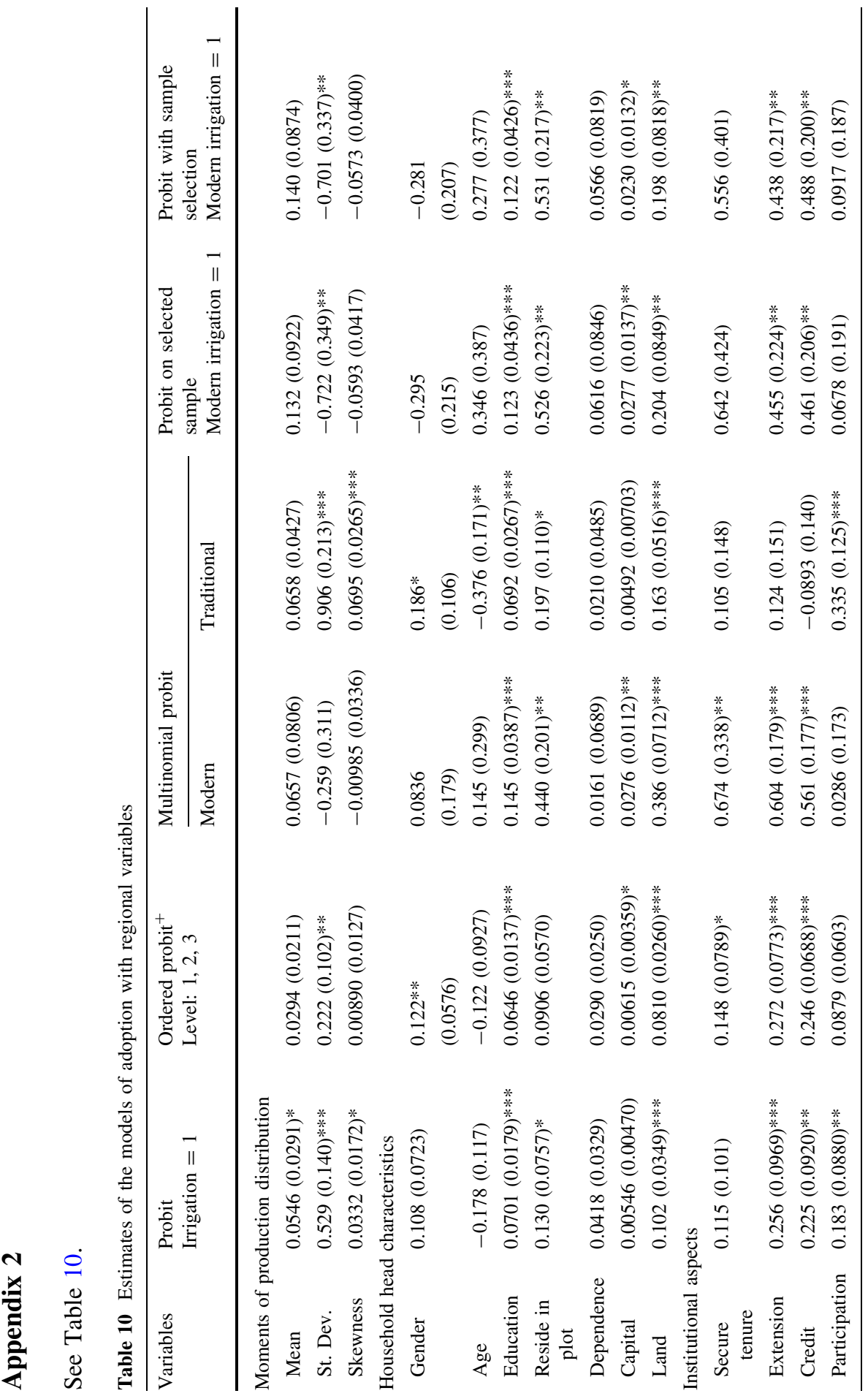




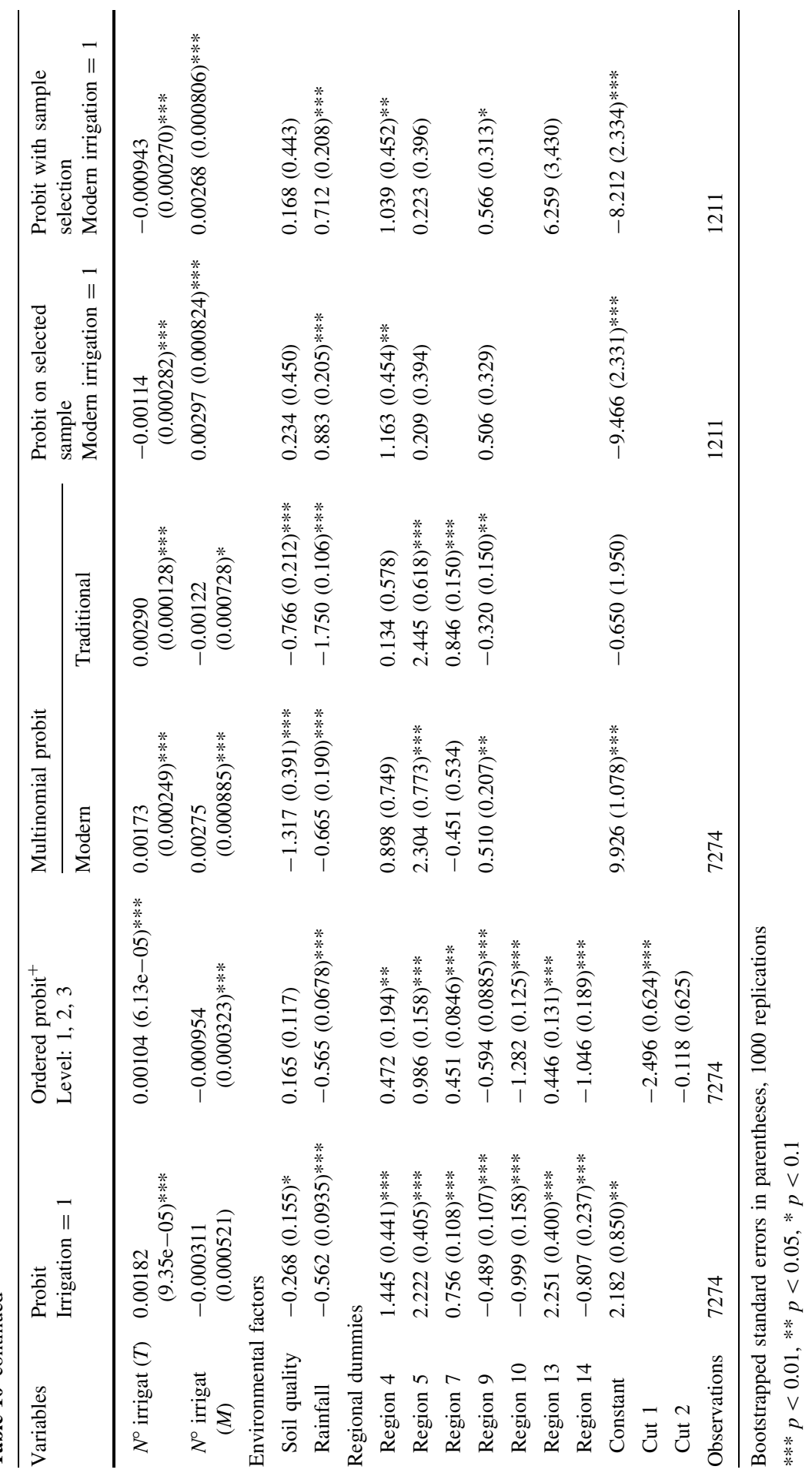




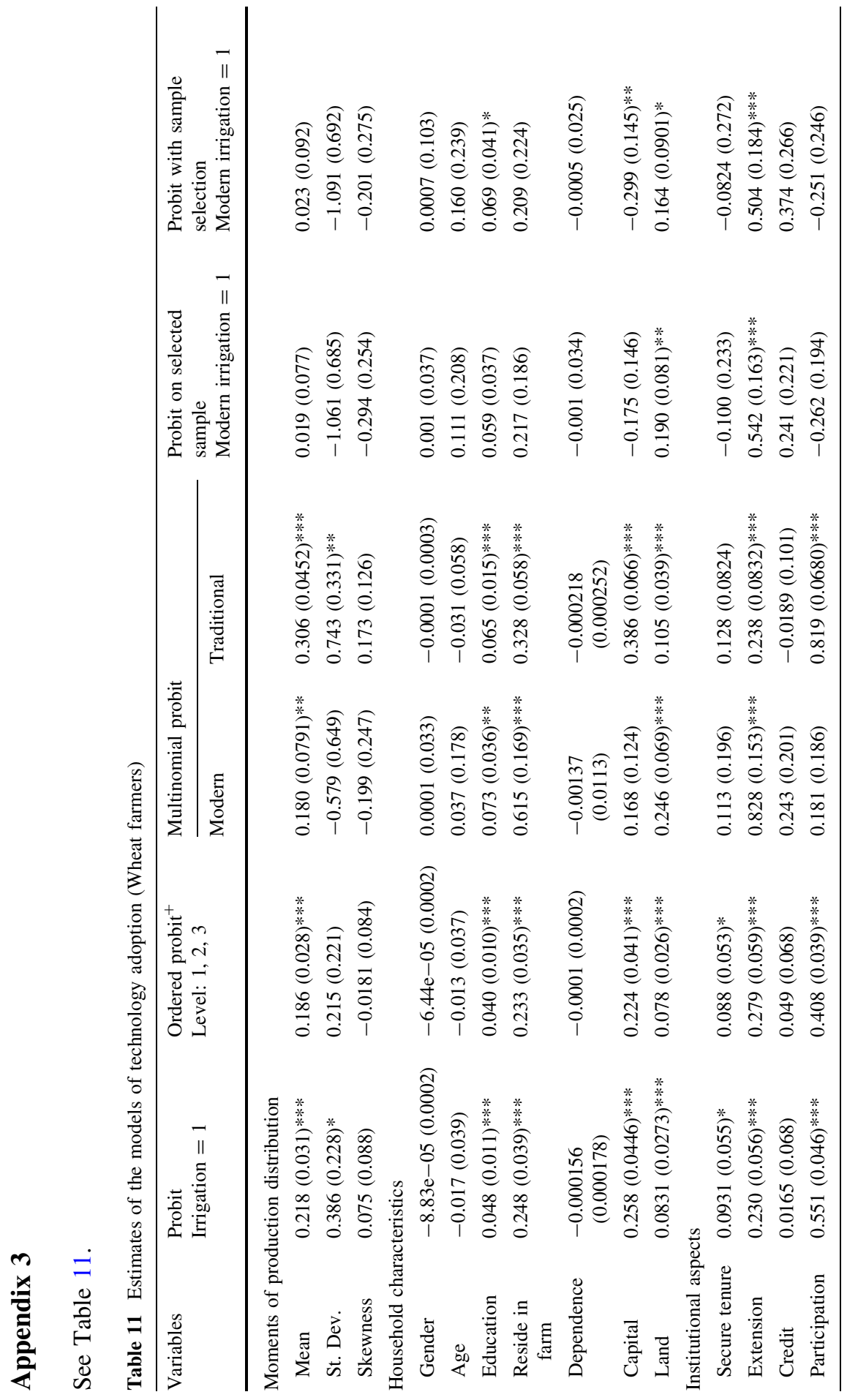




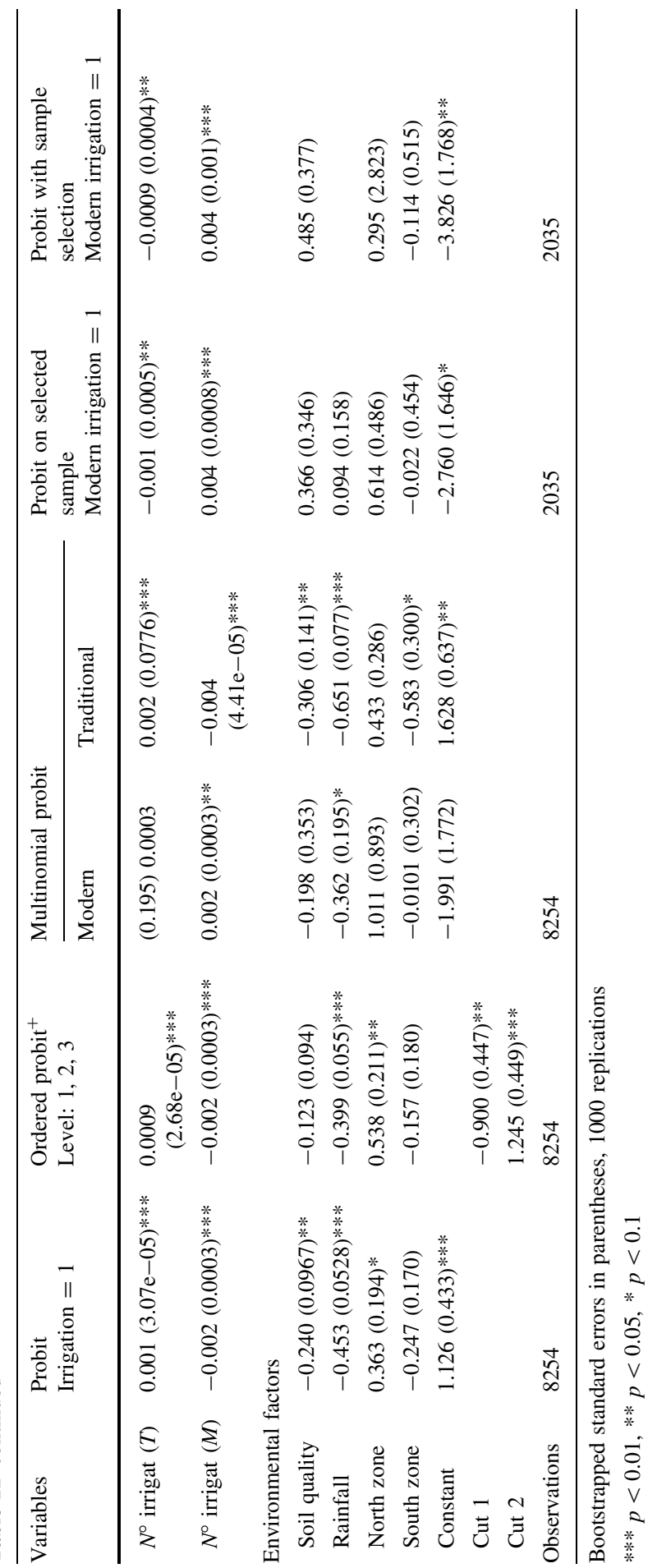




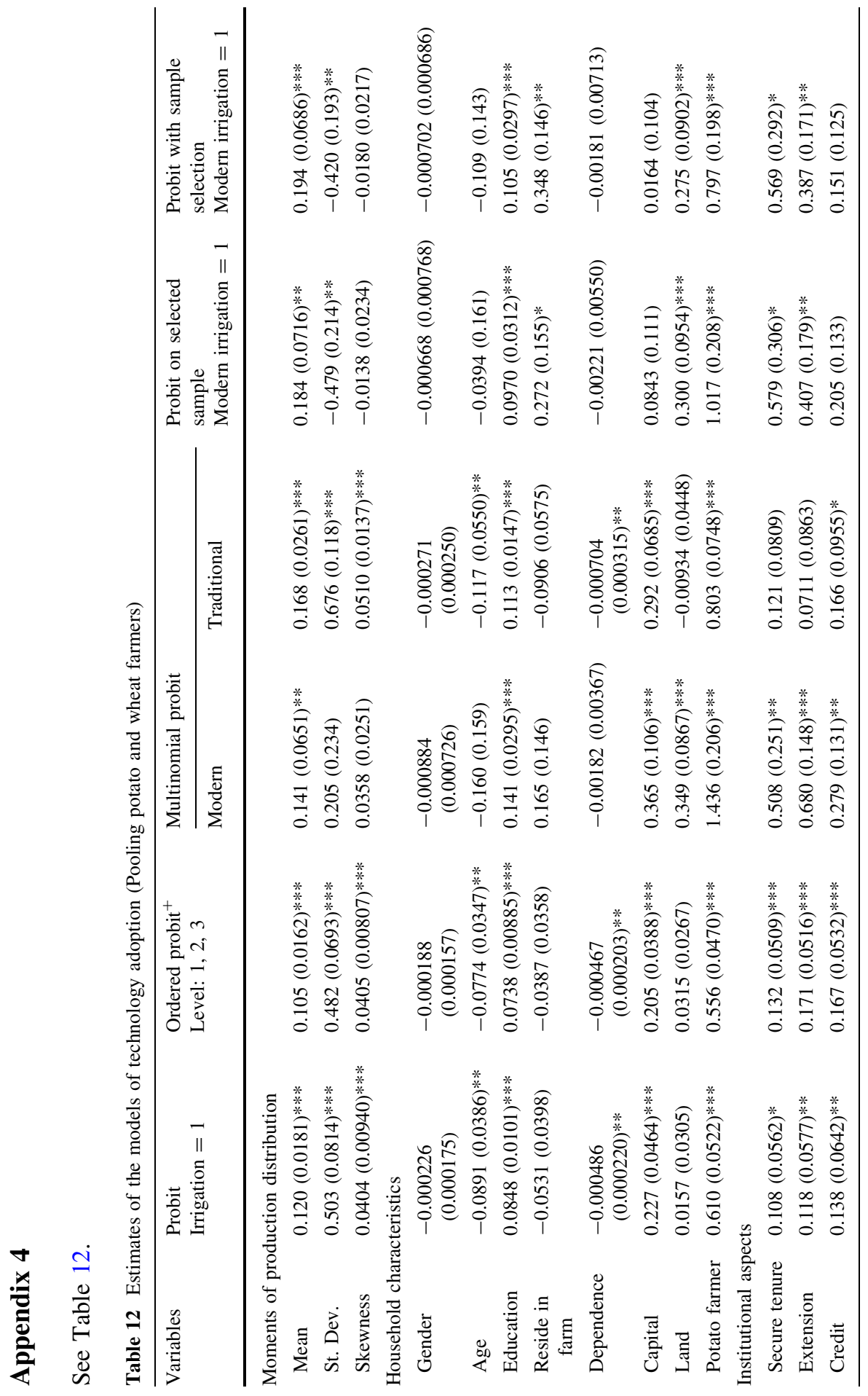




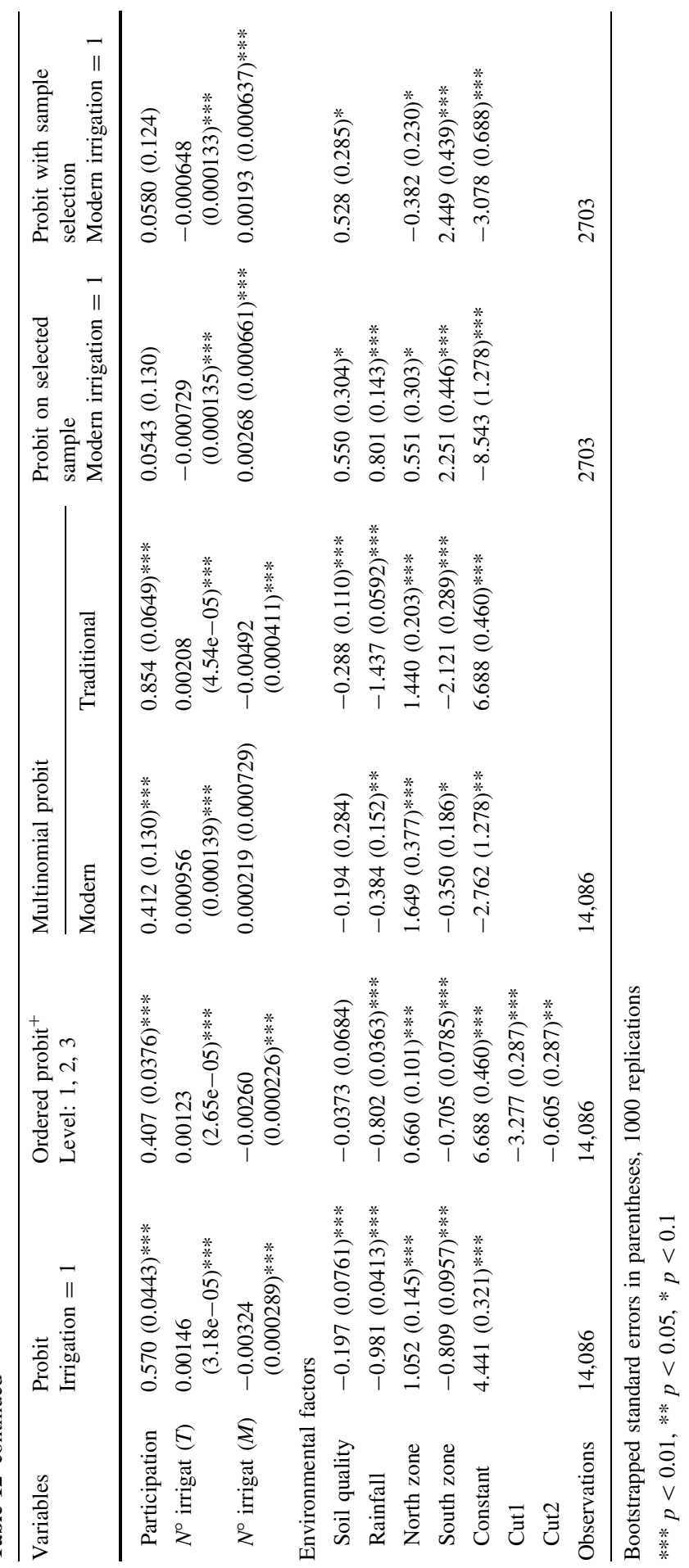




\section{Appendix 5}

See Table 13.

Table 13 Estimates of the models of technology adoption for rice farmers

\begin{tabular}{|c|c|}
\hline Variables & $\begin{array}{l}\text { Probit on selected sample } \\
\text { Modern irrigation }=1\end{array}$ \\
\hline \multicolumn{2}{|c|}{ Moments of production distribution } \\
\hline Mean & $0.174(0.624)$ \\
\hline St. Dev. & $-0.484(1.118)$ \\
\hline Skewness & $-0.0798(0.267)$ \\
\hline \multicolumn{2}{|c|}{ Household characteristics } \\
\hline Gender & $-0.000576(0.000825)$ \\
\hline Age & $-0.202(0.195)$ \\
\hline Education & $0.0312(0.0416)$ \\
\hline Reside in farm & $0.0696(0.179)$ \\
\hline Dependence & $-0.00207(0.00573)$ \\
\hline Capital & $0.230 *(0.120)$ \\
\hline Land & $0.0139(0.112)$ \\
\hline \multicolumn{2}{|c|}{ Institutional aspects } \\
\hline Secure tenure & $0.842(0.525)$ \\
\hline Extension & $0.168(0.187)$ \\
\hline Credit & $0.0586(0.129)$ \\
\hline Participation & $0.423 * * *(0.153)$ \\
\hline$N^{\circ}$ irrigat $(T)$ & $-0.000289(0.000230)$ \\
\hline$N^{\circ}$ irrigat $(M)$ & $0.00799 * * *(0.00284)$ \\
\hline \multicolumn{2}{|c|}{ Environmental factors } \\
\hline Soil quality & $-0.463(0.606)$ \\
\hline Rainfall & $0.0999(0.599)$ \\
\hline Constant & $-3.195(3.696)$ \\
\hline Observations & 1534 \\
\hline
\end{tabular}




\section{Appendix 6}

See Table 14.

Table 14 Correct predictions for adoption models per irrigation category

\begin{tabular}{|c|c|c|c|c|c|}
\hline $\begin{array}{l}\text { Irrigation } \\
\text { status }\end{array}$ & $\begin{array}{l}\text { Probit } \\
\text { Irrigation }=1 \\
\quad(\%)\end{array}$ & $\begin{array}{l}\text { Ordered } \\
\text { probit }^{+} \\
\text {Level: } 1,2, \\
3(\%)\end{array}$ & $\begin{array}{l}\text { Multinomial } \\
\text { probit (\%) }\end{array}$ & $\begin{array}{l}\text { Probit on } \\
\text { selected } \\
\text { sample } \\
\text { Modern } \\
\quad \text { irrigation = } 1 \\
\quad(\%)\end{array}$ & $\begin{array}{l}\text { Probit with } \\
\text { sample } \\
\text { selection } \\
\text { Modern } \\
\quad \text { irrigation = } 1 \\
\quad(\%)\end{array}$ \\
\hline \multicolumn{6}{|l|}{ Whole sample } \\
\hline $\begin{array}{l}\text { Correct } \\
\text { predictions }\end{array}$ & 94.6 & 93.6 & 94.2 & 95.1 & 96.1 \\
\hline $\begin{array}{l}\text { Non- } \\
\text { irrigation }\end{array}$ & 98.0 & 98.8 & 98.2 & - & 99.2 \\
\hline $\begin{array}{r}\text { Traditional } \\
\text { irrigation }\end{array}$ & - & 71.9 & 79.2 & 93.5 & 99.3 \\
\hline $\begin{array}{l}\text { Modern } \\
\text { irrigation }\end{array}$ & - & 1.4 & 1.4 & 28.6 & 42.9 \\
\hline \multicolumn{6}{|l|}{ Selected sample } \\
\hline $\begin{array}{l}\text { Correct } \\
\text { predictions }\end{array}$ & 89.6 & 87.1 & 88.7 & 95.1 & 95.5 \\
\hline $\begin{array}{l}\text { Non } \\
\quad \text { irrigation }\end{array}$ & 96.3 & 96.5 & 96.6 & - & 97.6 \\
\hline $\begin{array}{r}\text { Traditional } \\
\text { irrigation }\end{array}$ & - & 67.9 & 73.5 & 99.5 & 99.4 \\
\hline $\begin{array}{l}\text { Modern } \\
\text { irrigation }\end{array}$ & - & 1.7 & 1.7 & 24.1 & 32.8 \\
\hline
\end{tabular}

Predictions on non-irrigation choices in the probit model with sample selection correspond to selection equation predictions

\section{References}

Antle JM (1983) Testing for stochastic structure of production: a flexible moment-based approach. J Bus Econ Stat 1(3): 192-201

Antle JM (1987) Econometric estimation of producers' risk attitudes. Am J Agric Econ 69:509-522

Bahduri A (1973) A study in agricultural backwardness under semi-feudalism. Econ J 83:120-137

Bandiera O, Rasul I (2006) Social network and technology adoption in Northern Mozambique. Econ J 116(514):869-902

Bardhan P, Udry C (1999) Development microeconomics. Oxford University Press

Caswell M, Zilberman D (1985) The choices of irrigation technologies in California. Am J Agric Econ 67(2):224-234

Caswell M, Zilberman D (1986) The effects of well depth and land quality on the choice of irrigation technology. Am J Agric Econ 68(4):798-811

CIMI (2011) Agro-climatic year books. Seasons 1989-1990:2006-2007

CIREN (2010) Determinación de la erosión actual y potencial de los suelos de Chile. http://www.ciren.cl

Conley T, Udry C (2010) Learning about a new technology: pineapple in Ghana. Am Econ Rev 100(1):35-69 
Daberkow S, McBride W (2003) Farm and operator characteristics affecting the awareness and adoption of precision agriculture technologies in the US. Precision Agric 4(2):163-177

Dercon S (2002) Income risk, coping strategies and safety nets. World Bank Res Obs 17(2):141-166

Dessalegn T (2005) Modelling farm irrigation decisions under under rainfall risk in the White-Volta basis of Ghana. University of Bonn, Thesis

Dinar A, Yaron D (1990) Influence of quality and scarcity of inputs on the adoption of modern irrigation technologies. West J Agric Econ 15(2):224-233

Dinar A, Zilberman D (1991) The economics of resource-conservation, pollution-reduction technology selection. The case of irrigation water. Resour Energy 13:323-348

Doss CR (2006) Analyzing technology adoption using microstudies: limitations, challenges, and opportunities for improvement. Agric Econ 34:207-219

Evenson RE, Gollin D (2003) Assessing the impact of the green revolution, 1960-2000. Science 300:758-762

FAO (2009) Evolución de la agricultura familiar campesina en Chile en el periodo 1997-2007. Food and Agriculture Organization of the United Nations (FAO). Representation in Chile

FAO (2010) Gestión del riesgo de sequía y otros eventos climáticos en Chile. Food and Agriculture Organization of the United Nations (FAO). Representation in Chile

Feder G, Just RE, Zilberman D (1985) Adoption of agricultural innovations in developing countries: a survey. Econ Dev Cult Change 33(2):255-298

Foltz J (2003) The economics of water-conserving technology adoption in Tunisia: an empirical estimation of farmer technology choice. Econ Dev Cult Change 51(2):359-373

Foster A, Rosenzweig M (1995) Learning by doing and learning from others: human capital and Technical change in agriculture. J Polit Econ 103(6):1176-1209

Foster A, Rosenzweig M (2010) Microeconomics of technology adoption. Ann Rev Econ 2:395-424

Foudi S, Erdlenbruch K (2012) The role of irrigation in farmers' risk management strategies in France. Eur Rev Agric Econ 39(3):439-457

Gebremedhin B, Swinton S (2003) Investment in soil conservation in northern Ethiopia: the role of land tenure security and public programs. Agric Econ 29(1):69-84

Green G, Sunding D, Zilberman D (1996) Explaining irrigation technology choices. A microparameter approach. Am J Agric Econ 78(4):1064-1072

He Xue-Fenget, Huhua C, Feng-Min L (2007) Econometric analysis of the determinants of adoption of rainwater harvesting and supplementary irrigation technology (RHSIT) in the semiarid Loess Plateu of China. Agric Water Manag 89:243-250

INDAP (2011) Statistical figures. Instituto de Desarrollo Agropecuario, Santiago, Chile. http://portal. indap.cl/content/view/1106/95/. Accessed 25 May 2011

INE (2007) VII Censo Nacional Agropecuario y Forestal, Instituto Nacional de Estadística (INE), Santiago, Chile

INIA (2006) Manual de producción de papa para la agricultura familiar campesina (A.F.C), Boletín No. 147, Instituto de Investigaciones Agropecuarias

Isham J (2002) The effect of social capital on fertilizer adoption: evidence from rural Tanzania. J Afr Econ 11(1):39-60

Just RE, Zilberman D, Rausser GC, Yaron D, Tapiero C (1980) A putty-clay approach to the distributional effects of new technology under risk. In: Operations research in agriculture and water resources. North Holland Publishing Company, New Yourk

Khana M, Zilberman D (1997) Incentives, precision technology and environmental protection. Ecol Econ 23:25-43

Koundouri P, Nauges E, Tzouvelekas V (2006) Technology adoption under production uncertainty: theory and application to irrigation technology. Am J Agric Econ 88(3):657-670

Lee D (2005) Agricultural sustainability and technology adoption: issues and policies for developing countries. Am J Agric Econ 87(5):1325-1334

Ministerio de Agricultura (MINAGRI) (2006) Chile potencia alimentaria. Documento base para la elaboración de una agenda pro-competividad, Ministerio de Agricultura

Ndiritu S, Kassie M, Shiferaw B (2014) Are there systematic gender differences in the adoption of sustainable agricultural intensification practices? Evidence from Kenya. Food Policy 49:117-127

Negri HD, Brooks D (1990) Determinants of irrigation technology choice. West J Agric Econ 15(2):213-223

Negri HD, Gollehon NR, Aillery MP (2005) The effect of climate variability on US irrigation adoption. Clim Change 69:299-323 
Ruttan VW (2002) Productivity growth in world agriculture: sources and constraints. J Econ Perspect 16(4):161-184

Schuck E, Frasier W, Webb R, Ellingson L, Umberger W (2005) Adoption of more technically efficient irrigation systems as a drought response. Water Resour Develop 21(4):651-662

Shrestha RB, Gopalakrishnan C (1993) Adoption and diffusion of drip irrigation technology: an econometric analysis. Econ Dev Cult Change 41(2):407-418

Skaggs RK (2001) Predicting drip irrigation use and adoption in a desert region. Agric Water Manag 51:125-142

Soule M, Tegene A, Wiebe K (2000) Land tenure and the adoption of conservation practices. Am J Agric Econ 82(4):993-1005

Sunding DL, Zilberman D (2001) The agricultural innovation process: research and technology adoption in a changing agricultural sector. Handb Agric Econ Agric Prod 1:207-261

Torkamani J, Shajari S (2008) Adoption of new irrigation technology under production risk. Water Resour Manage 22:229-237

Udry C (1994) Risk and insurance in a Rural credit market. An empirical investigation in Northern Nigeria. Rev Econ Stud 61:495-526

Van de Ven WPMM, Van Pragg BMS (1981) The demand for deductibles in private health insurance: a probit model with sample selection. J Econom 17:229-252

Wooldridge J (2010) Econometric analysis of cross section and panel data, 2nd edn. The Mit Press Cambridge, Massachusetts

Zilberman D, Khanna M, Lipper L (1997) Economics of new technologies for sustainable development. Aust J Agric Resour Econ 41(1):63-80 